Board of Governors of the Federal Reserve System

\author{
International Finance Discussion Papers
}

Number 578

March 1997

\title{
REGIONAL LABOR FLUCTUATIONS: \\ OIL SHOCKS, MILITARY SPENDING, AND OTHER DRIVING FORCES
}

Steven J. Davis, Prakash Loungani, and Ramamohan Mahidhara

NOTE: International Finance Discussion Papers are preliminary materials circulated to stimulate discussion and critical comment. References in publications to International Finance Discussion Papers (other than an acknowledgment that the writer has had access to unpublished material) should be cleared with the author or authors. Recent IFDPs are available on the Web at www.bog.frb.fed.us. 


\title{
REGIONAL LABOR FLUCTUATIONS: \\ OIL SHOCKS, MILITARY SPENDING, AND OTHER DRIVING FORCES
}

Steven J. Davis, Prakash Loungani, and Ramamohan Mahidhara*

\begin{abstract}
We quantify the contribution of various driving forces to state-level movements in unemployment rates and employment growth from 1956 to 1992. Our story of regional fluctuations in the U.S. economy has a large cast of players -- including government contract awards and the basing of military personnel -- but oil price shocks have been the leading actor since 1973. Beyond the magnitude and abruptness of oil price movements, the explanation for their pronounced regional effects has three essential elements: (i) regions differ in industry mix, (ii) industries differ in sensitivity to movements in the relative price of oil, and (iii) the reallocation of productive factors across industries and regions is costly and timeconsuming.

Our study provides estimates of the costs of creating regional jobs and reducing regional unemployment through the awarding of military contracts. Based on the BLS measure ofstate employment, our baseline specifications imply that creating one local job-year requires national government purchases from local firms in the amount of $\$ 56,000$ to $\$ 91,000$ (measured in 1982 dollars). The estimated cost of job creation is more than twice as large for the broader CPS measure. Econometric specifications that consider demand spillovers across state boundaries deliver job creation cost estimates roughly $40-45 \%$ smaller.

We find asymmetric unemployment responses to positive and negative regional shocks. Negative shocks -- whether involving increases in oil prices, or scaling back of contract awards and military bases -- have a greater impact than equal-sized positive shocks. This evidence implies that shocks to the spatial structure of demand (e.g., a reallocation of government contract awards) cause short-run increases in aggregate unemployment.

State-level unemployment responses to regional shocks persist for several years. Net migration of people and workers between states is the dominant equilibrating mechanism that brings regiond unemployment rates back into alignment.

Keywords: regional cycles; oil shocks; defense expenditures; military bases; unemployment

* Loungani: International Finance Division, Federal Reserve Board; Davis: University of Chicago and NBER; Mahidhara: Amoco Corporation. We acknowledge very useful comments from Valerie Ramey (our discussant at an NBER conference), Tim Bartik, Danny Blanchflower, Randy Eberts, Chris Erceg, Mark Hooker, Joyce Zickler, and seminar participants at numerous venues including an October 1996 conference on "International Energy Security: Economic Vulnerability to Oil Price Shocks"organized by the Department of Energy and the Department of State. We thank Olivier Blanchard and Larry Katz for state-level data on employment, Merrill Wegner for Department of Defense prime contract awards and personnel, Herbert Baker for NASA prime contract awards, Wayne Vroman for state-level civilian unemployment rates, and Patrick Kennedy for industry stock return data. Davis gratefully acknowledges research support from the U.S. National Science Foundation and the U.S. Department of Energy. The views in this paper are solely the responsibility of the authors and should not be interpreted as reflecting the views of the Board of Governors of the Federal Reserve System or of any other person associated with the Federal Reserve System.
\end{abstract}




\section{Introduction}

Regional fluctuations in economic fortunes are large and persistent, and they attract keen interest from economists, regional scientists, journalists and policymakers. ${ }^{1}$ We focus on labor market outcomes and advance our understanding of regional fluctuations in several related respects: First, we quantify the contribution of various driving forces to regional movements in unemployment rates and employment levels. In the process, we construct new measures of regional economic disturbances that could fruitfully be applied to several other aspects of regional fluctuations. Second, we estimate the cost of creating local jobs and the cost of reducing local unemployment through national government purchases of goods and services from local firms. Third, we characterize the dynamic process by which regional labor markets gravitate towards long-run outcomes in the wake of the various disturbances. Last, as a by-product of studying the driving forces behind regional

${ }^{1}$ Reasons for this interest are highly varied, as suggested by the following list: regional fluctuations provide a useful testing ground for theories of risk sharing and cross-country growth differences; the history of U.S. regional experiences provides a laboratory for gauging the potential consequences of greater European economic integration and currency union; oil price shocks appear to induce greatly disparate effects among regions; recent and ongoing cutbacks in U.S. defense spending fall highly unevenly across regions; the timing and magnitude of post-1979 increases in U.S. earnings inequality and returns to education differ sharply among U.S. regions; real estate values, vacancy rates, transactions volumes and construction activity exhibit pronounced region-specific cycles. Research on these topics includes recent work by Asdrubali et al (1996), Barro and Sala-i-Martin (1991, 1992), Bartik (1991), Blanchard and Katz (1992), Borjas and Ramey (1995), DiPasquale and Wheaton (1996), Eberts and Stone (1992), Eichengreen (1990), Hooker and Knetter (1996), Meehay and Solnick (1990), Rosen and Topel (1988), and Topel (1994). 
fluctuations, we develop new evidence that shocks to the spatial and industry structure of demand play a role in driving aggregate employment and unemployment fluctuations.

A central premise of our study is that regions differ in the bundle of goods and services they produce. Further, these regional differences in industry mix reflect a deployment of capital and labor inputs that are specialized in terms of both location and industry. The specialized nature of inputs impedes their redeployment to alternative uses in response to regional disturbances, whether the disturbances are intrinsically spatial or simply reflect disparate regional effects of shocks to the industry structure of demand. Consequently, shocks to the spatial or industry structure of demand give rise to regional differentials in wages, unemployment and capital utilization.

These differentials, in turn, bring about changes in regional labor force participation, a redeployment of capital and workers within regions, migration of workers from adversely to favorably affected regions, and regional flows of capital and jobs. The speed and character of these equilibrating forces determine the adjustment of relative regional employment, unemployment and labor force participation to regional disturbances.

We directly measure a broad range of disturbances, which enables us to quantify their relative importance and investigate whether they trigger qualitatively different dynamic responses. The regional disturbances, or "driving forces", that we consider fall into the following categories:

1. Spatial and time variation in military expenditures, as measured by Department of Defense (DoD) and National Aeronautics and Space Administration (NASA) prime contract awards to firms in the region.

2. Changes in the number of military personnel in a region (relative to population) arising, for example, from base closings.

3. Fluctuations in the price of oil interacted with regional differences in the mix of oil- 
sensitive industries.

4. Spatial and time variation in the magnitude of shocks to the intra-region structure of demand, as proxied by region-time-specific measures of the cross-industry dispersion in equity returns.

5. The nonneutral effects of national disturbances - other than oil price and military expenditure shocks - that differentially affect regional economies because of regional differences in industry mix. Nonneutral effects of this sort potentially arise because of exchange rate movements, changes in the stance of monetary policy, regulatory changes, tax reforms and many other events.

Defense contract awards and base closings attract considerable attention in the popular media and in discussions of economic policy, but we find that other disturbances - especially oil price shocks - have played larger roles as driving forces behind regional fluctuations. Nonetheless, we find sizable unemployment and employment responses to military expenditure shocks, too. Indeed, every type of disturbance listed above operates as an important driving force behind particular episodes or certain aspects of regional labor market fluctuations.

Our estimated effects of these disturbances and our characterization of regional dynamics derive from a large panel data set that contains annual observations from 1954 to 1992 for all 50 states and the District of Columbia. ${ }^{2}$ Previous studies typically rely on shorter panels or a smaller number of states or other regional units. The longer panels and larger set of measured driving forces in our study underlie our sharper and richer characterization of regional fluctuations.

We investigate the joint dynamics of regional unemployment, employment and labor force participation in order to characterize the adjustment process triggered by the driving

\footnotetext{
${ }^{2}$ For brevity, we grant statehood to D.C. and henceforth refer to the entire group as states.
} 
forces. We conclude, as do Blanchard and Katz (1992), that migration responses to regional economic disturbances help insulate state unemployment rates from regional shocks, especially in years subsequent to the impact effects. To a large extent, the longer term imprint of these shocks shows up on the distribution of employment among regions, rather than on regional differences in unemployment rates. Unlike Blanchard and Katz, we also develop evidence that the rapidity of the migration response varies by category of shock, and we find that the migration response is misstated by estimates that rely on the Bureau of Labor Statistics (BLS) measure of state employment rather than the broader Current Population Survey (CPS) measure.

We estimate the cost, in terms of national government expenditures, of creating local jobs and reducing local unemployment using several employment and unemployment measures and a variety of econometric specifications. Based on the BLS measure of state employment and annual discount rates in the range of $3-10 \%$, our baseline specifications imply that creating one local job-year requires national government purchases from local firms in the amount of 56-91 thousand 1982 dollars. The estimated cost of job creation is more than twice as large for the broader CPS employment measure, and the cost of purchasing local unemployment reductions ranges from 800 thousand to 2.1 million dollars per person-year. Econometric specifications that consider demand spillovers across state boundaries deliver job creation cost estimates roughly $40-45 \%$ smaller. Specifications that allow for asymmetric effects indicate that expenditure reductions have nearly twice the impact on local unemployment as expenditure increases. Hooker and Knetter (1996) find similarly asymmetric employment effects of local defense purchases.

Several aspects of our empirical findings buttress the view that allocative shocks play a role as driving forces behind aggregate fluctuations. ${ }^{3}$ First, we develop compelling evi-

${ }^{3}$ Davis, Haltiwanger and Schuh (1996, chapter 5) review several theories of how allocative 
dence that oil price shocks have been major driving forces behind regional employment and unemployment fluctuations, and that the transmission mechanism involves their impact on the industry structure of derived demand. This evidence comes from econometric specifications that isolate the state-specific time-series covariation between state-level outcomes and state-specific measures of oil price shocks. It is therefore distinct from the aggregate time-series evidence considered by Hamilton (1983) and many others, and in certain important respects less subject to difficulties of interpretation, because our panel data enable us to condition on unobserved aggregate disturbances that might be correlated with oil price shocks. ${ }^{4}$

Second, like Loungani, Rush and Tave (1990) and Brainard and Cutler (1993), we find that a rise in the dispersion of stock returns across industries leads to an increase in unemployment. We interpret this finding as evidence that shocks to the structure of demand generate unemployment increases because of frictions in the process of reallocating workers and jobs. Unlike previous studies, however, our evidence rests on state-specific time-series covariation between unemployment and the dispersion of equity returns.

Third, for all three categories of explicitly measured shocks in this study - the basing of military personnel, prime contract awards, and oil price shocks - we find mild or strong evidence that negative shocks have a greater effect on state-level unemployment than positive shocks of the same magnitude. This evidence of asymmetry confirms a basic prediction of theories that stress the role of allocative disturbances as driving forces behind

shocks drive aggregate fluctuations.

${ }^{4}$ Mork (1994) ably reviews the large literature that investigates whether oil price shocks drive aggregate fluctuations and, if so, through what channels. Hooker (1996) and Hamilton (1996) engage in an interesting exchange that illustrates how limited statistical power hampers interpretation of the aggregate time-series evidence. 
aggregate fluctuations. In particular, the evidence suggests that allocative disturbances do not "average out" in terms of their short-run impact on aggregate unemployment. Instead, periods with unusually intense allocative disturbances also involve greater aggregate unemployment, other things equal. As a related piece of evidence, we find that the dispersion of unemployment rates among states varies considerably over time (after conditioning out state fixed effects). Much of this variation is explained by our measured driving forces.

The rest of the paper is organized as follows. Section 2 describes the state-level employment and unemployment data and provides a statistical characterization of regional labor fluctuations in terms of a simple variance components model. Section 3 describes the driving forces and characterizes important aspects of their time-series and cross-state variation. Section 4 estimates the effects of the driving forces on the regional cycle component of civilian and insured unemployment rates. We consider specifications that accommodate regional spillovers and possibly asymmetric effects of positive and negative shocks. We also quantify the success of the regression models in accounting for time and cross-state variation in the regional cycle component of unemployment fluctuations. Section 5 considers VAR models of the joint dynamics of state-level unemployment, employment and labor force participation plus oil shock and military spending variables. We estimate the cost of creating local jobs and reducing local unemployment using both the VAR and unemployment regression models. Section 6 summarizes the evidence and concludes.

\section{Basic features of regional labor fluctuations}

\subsection{State-level unemployment and employment measures}

We treat individual states as regional units and consider two measures of unemployment: (i) the civilian unemployment rate and (ii) the insured unemployment rate, defined as the number of unemployment insurance (UI) claimants divided by the number of jobs 
covered by the UI system. The data extend from 1948 to 1992 for insured unemployment and from 1957 to 1992 for civilian unemployment. ${ }^{5}$

There are well-known conceptual differences between the two unemployment measures. Insured unemployment is an administrative count of persons who file claims under the UI programs of the various states. ${ }^{6}$ The level of civilian unemployment, in contrast, is an estimated count of persons seeking jobs, regardless of their eligibility for UI benefits or previous labor force experience. Young workers, women, and workers in service and government industries are less likely to be eligible for UI benefits, so they tend to be under-represented in the UI count.

In light of these differences, it is unsurprising that the co-movement between the two measures is less than perfect. Over the 1958 to 1992 period, the median correlation between the two state-level unemployment rate measures is .58; one-quarter of the correlations are less than .43 . The median correlation rises to .91 when we exclude the period after $1979 .^{7}$

We also consider two employment measures that have important conceptual differences. The Bureau of Labor Statistics (BLS) estimates employment using a large survey of nonagricultural business establishments. The BLS figure reflects the number of paid positions, so that persons with two jobs in the covered sector are counted twice. The BLS measure excludes self employment, agricultural and private household employment, and military personnel. The Current Population Survey (CPS) provides a broader measure of ${ }^{5}$ Some data for Alaska and Hawaii are unavailable prior to 1960.

${ }^{6}$ To be included in the count, the claimant must have been employed in a job that is covered by the UI program, his employınent must have ended involuntarily, and he must meet other eligibility criteria determined by the UI laws of each state. See Green (1971) for a detailed discussion.

${ }^{7}$ Burtless (1983), Blank and Card (1991) and Vroman (1991) analyze the post-1979 divergence between insured and total unemployment rates at the national level. 
all civilian employment, based on a monthly household survey.

At the national level, the ratio of BLS to CPS employment rose from $81.5 \%$ in 1958 to $91.5 \%$ in 1992 , with most of the increase occurring during the 1960 s. At the state level, the median correlation between employment-population ratios based on the BLS and CPS measures is .98 over the 1958 to 1992 period.

\subsection{The magnitude and persistence of regional cycles}

Following Marston (1985), we use a simple variance components model to group the factors that drive variation in unemployment rates across time and space into three basic categories:

$$
\begin{aligned}
& U_{s t}=\gamma_{t}+\alpha_{s}+\epsilon_{s t}, \\
& \epsilon_{s t}=\rho \epsilon_{s, t-1}+\eta_{s t} .
\end{aligned}
$$

$U_{s t}$ refers to the unemployment rate (or employment-population ratio) in state $s$ in period $t$.

The $\gamma_{t}$ term captures factors that shift aggregate labor demand and supply and cause similar time-series movements in national and state unemployment rates. The $\alpha_{s}$ term reflects differences in amenities, labor market institutions, the parameters of the UI system, and other aspects of the economic enviromment that induce differences among states in their natural unemployment rates. Since differences in these factors are likely to remain stable or change slowly over time, they lead to persistent unemployment differentials.

Given costly labor and capital mobility, unemployment differentials also arise from labor demand and supply disturbances with differential effects among states. These effects, which we henceforth refer to as "regional cycles", are captured in the model above by the term $\epsilon_{s t}$. The disturbances that drive regional downturns give rise to an out-migration of workers and an in-migration of jobs that tend, over time, to ameliorate the unemployment 
differentials triggered by the disturbances. The parameter $\rho$ tells us about the speed of the adjustment mechanisms: $(1-\rho)$ is the fraction of the unemployment differential eliminated in one year by changes in labor force participation and by the migration of workers and jobs. The continuous arrival of new random disturbances - represented by $\eta_{s t}$ in equation (2) - generates continuous variation in the regional cycle component of geographic unemployment differentials.

The statistical model (1) and (2) does not generate orthogonal components, and there are good reasons to believe that the three sources of variation in state unemployment rates are interdependent. The model is still useful for assessing the relative importance of each source of variation in state-level labor fluctuations and for summarizing the persistence of the regional cycle component.

Estimates of the model appear in Table 1. According to column (1), the standard deviation of the civilian unemployment rate is 2.21 . The next three rows report standard deviations of the state fixed effects $(\alpha)$, the year fixed effects $(\gamma)$, and the regional cycle component $(\epsilon)$. It is evident that all three components play an important role in accounting for state unemployment rate variation. The standard deviation of the regional cycle component of the civilian unemployment rate $\left(\sigma_{\epsilon}^{2}\right)$ is 1.86 percentage points, and its variance equals $71 \%$ of the total variance. The variances of the state and year fixed effects amount to $39 \%$ and $43 \%$, respectively, of the total variance in civilian unemployment rates. Results for the insured unemployment rate also point to a large role for each component, especially the regional cycle component. While state and year fixed effects certainly cannot be ignored, Table 1 shows clearly that the regional cycle component on which we focus is a major source of variation in state unemployment rates.

Another important message of the table involves the persistence of the regional cycle component. For both the civilian and insured unemployment rates, the estimate of $\rho$ is 
about 0.70 . That is, $30 \%$ of the unemployment differential is eliminated in one year. ${ }^{8}$

Columns 3 and 4 of Table 1 report the results of fitting the model to two alternative measures of the employment-population ratio. Based on the CPS employment measure, the regional cycle component of employment rate fluctuations accounts for $31 \%$ of the total variation, about the same as the state or year effects. The estimate for $\rho$ of .87 implies greater persistence of regional movements in the employment-population ratio than in the unemployment rate.

The results for the other measure of the employment-population show a sharply different pattern, and they point to potential inference pitfalls associated with the BLS emloyment measure. Three results merit attention: First, the raw standard deviation of the employment-population ratio is nearly 9.7 percentage points using the BLS employment measure, as compared to only 5.2 percentage points using the broader CPS measure. Second, the standard deviation of the estimated state fixed effects is more than four times larger using the BLS employment measure. Third, the regional cycle component is much more persistent and its variability much greater using the BLS measure.

These results indicate that persistent differences among states in the industrial and

${ }^{8}$ Marston found much less persistence in the regional cycle component of metropolitan unemployment rates. Migration responses are probably more rapid in Marston's data, because he defines regions more narrowly. Marston also uses a much shorter sample period. When we re-estimate the model using Marston's 1970-78 sample period, our estimate of $\left(\sigma_{\epsilon}^{2} / \sigma_{u}^{2}\right)$ drops to 30 percent for the civilian unemployment rate and to 13 percent for the insured unemployment rate. The estimate of $\rho$ drops to .37 and .18 for the civilian and insured unemployment rates, respectively, suggesting much lower persistence in the regional cycle component. Evidently, it is difficult to disentangle persistent regional cycles from region fixed effects in short panels. 
occupational mix of employment account for much of the cross-state variation in BLSbased employment-population ratios. Furthermore, and more importantly for our study, regional shocks generate much more persistent responses in the mix of employment (between BLS covered and uncovered sectors) than in the level of employment. Because of the potential for confounding employment composition and employment level effects, it is dangerous to rely solely on BLS employment data to draw inferences about the magnitude and persistence of employment and migration responses to regional disturbances.

\section{The driving forces behind regional fluctuations}

In this section we describe the driving forces behind regional unemployment and employment fluctuations, and we characterize some important aspects of cross-state and timeseries variation in the measures.

\subsection{Defense and NASA expenditures}

\section{Prime contract awards}

Like several other studies, we use DoD prime contract awards as a measure of regional defense expenditures. ${ }^{9}$ We supplement the DoD figures with data on NASA prime contract awards to obtain a more comprehensive measure of "military" contract awards by state. The prime contract awards data exhibit a great deal of state-specific time variation and provide considerable leverage for estimating the effects of federal procurement on regional economies. The state-specific variation reflects wide swings in national military expenditures, coupled with a highly uneven spatial distribution, and pronouced changes in the spatial distribution over time. We treat state-level variation in prime contract awards as exogenous with respect to state-level omployment and unemployment outcomes, an

\footnotetext{
${ }^{9}$ See Crump (1989), Mehay and Solnick (1990), Markusen et al (1991), Mayer (1991) and Hooker and Knetter (1996).
} 
approach strongly supported by the evidence and studies discussed below.

Figure 1 plots real military prime contract awards per capita in the United States from 1954 to 1992 in 1982 dollars (based on the GDP implicit deflator for personal consumption expenditures). As discussed by Crump (1989) and Markusen et al (1991), there are four major episodes in the behavior of military contract awards over the post-Korean War period: (i) the increase in defense expenditures associated with the onset of the Cold War (1954 to 1964), (ii) the escalation and subsequent scaling back of defense expenditures associated with the Vietnam war (1965 to 1975), (iii) the re-building of defense capabilities under Carter and Reagan (1976 to 1985) and (iv) the defense cutbacks associated with the end of the Cold War (1986 to 1992). Figure 1 also shows prime contract awards by NASA, which reached about one-seventh the size of DoD contracts at their peak in 1964-65.

The four episodes in national defense expenditures were associated with pronounced shifts in the spatial distribution of expenditures, as illustrated by movements in relative contract awards for selected states in Figure 2. Colorado gained, relative to the U.S. as a whole, from the shift in defense expenditures towards the production and basing of missile systems. Georgia's relative contracts rose and fell over the course of the Vietnam war, and Massachusetts gained from the shift towards high-tech weapon systems that began in the mid-1960's. California and Washington experienced declines in relative contract awards in the post-Cold-War period, even as national expenditures dropped off by more than one-third. In a pattern typical of several states, Illinois had small contract award levels throughout the entire period of our study. Connecticut, in contrast, experienced very high and variable contract awards per capita.

Figures 1 and 2 point to considerable state-level variation in prime contract awards per capita. The pattern of variation and its apparent connection to political and national security developments suggest that the variation is exogenous with respect to state-level 
economic fortunes. More extensive and systematic studies of the determinants of military contract awards strongly support this conclusion. Markusen et al (1991) describe and explain the postwar evolution in the spatial distribution of U.S. military expenditures in great detail. Remarkably, in their 25-page chapter devoted to a "theory of militaryindustrial places", the notion that the U.S. government targets military contract awards to localities or regions with depressed labor markets receives less than two lines (p. 43). Other chapters in the book devoted to case studies and particular regional experiences almost never mention the idea. Mayer (1991) studies the role of Congress, and the political process more generally, in the awarding of defense contracts. He concludes (p. 210) that "the Pentagon does not, indeed cannot, distribute defense contracts (as opposed to bases) for political purposes." Where the expenditures process is most responsive to political forces, as in the allocation of subcontract awards, the relevant considerations are the spreading of awards to many districts and the targeting of awards to the states or districts of influential members of Congress, not the targeting of awards to depressed regions.

\section{Basing of military personnel}

Contract awards comprise roughly half of defense spending, and compensation of DoD personnel accounts for most of the rest. We measure regional variation in the compensation component of military expenditures by the ratio of DoD employment to population. This ratio exhibits wide swings at the national level and considerable spatial variation.

Figure 3 plots the ratio of domestically based DoD personnel to the U.S. population from 1954 to 1992 . The ratio declined sharply in the first several years after the Korean War, fluctuated in the early 1960s, and then rose sharply between 1964 and 1969 as the U.S. expanded military activities in Southeast Asia. The ratio declined steeply after 1969 and throughout most of the 1970s. Declines resumed after the end of the Cold War in the middle 1980s. 
Two other time series plotted in Figure 3 provide summary information about the magnitude and variation of changes in the state-level ratio of DoD employment to population. Peaks in the mean absolute change in the DoD employment-population ratio occur in 1959, 1965 and 1970. The cross-state variation of changes in the ratio peaks in 1959 and 1964. Both summary measures indicate that larger state-level movements in the ratio of DoD employment to population primarily occur in the first half of the sample. ${ }^{10}$

Changes in the aggregate number of U.S. military personnel are clearly exogenous with respect to regional economic conditions, and these aggregate developments drive much of the state-level variation. Anecdotal evidence, however, suggests that decisions about the basing of military personnel reflect a large measure of pork barrel politics. Mayer (1991, pp. 139-142) provides several examples, and his account confirms that political forces play an important role in base siting and closing decisions. Nonetheless, Mayer's description points to a preferential treatment for regions represented by well-situated and influential members of Congress, not to a preferential treatment for depressed regions that would give rise to an endogeneity bias in our regression models. If military personnel cutbacks are systematically steered away from depressed regions, or if expansions are directed toward depressed regions, our estimates below understate the true effects of exogenous changes on regional unemployment.

\section{Military expenditure regressors}

Our regression models separately treat military contract awards and the basing of military personnel. We let $C O N_{s t}$ denote the change from $t-1$ to $t$ in real per capita prime contracts awards (DoD plus NASA) for state $s$, and we let $M I L_{s t}$ denote the change in the DoD employment-population ratio.

\footnotetext{
${ }^{10}$ When Alaska and D.C. are included, the mean absolute change and the standard deviation of changes are moderately larger and much more variable over time.
} 
Regional economists have long recognized that military contract awards generate "spillover" effects on other states through product demand and labor market channels. Prime contract award recipients typically purchase labor and materials from other states. In addition, prime contract awards are partly subcontracted to firms operating in other states. ${ }^{11}$

To capture these spillovers in a simple way, we model state-level outcomes as dependent on own military expenditures and on prime contract awards and DoD personnel changes in other states that belong to the same Census geographic region. In particular, we let $C O N R$ denote the change in per capita contracts awards to other states in the Census region, and we let MILR denote the change in the DoD employment-population ratio in the other states in the region. ${ }^{12}$

\subsection{Oil price shocks}

Oil price shocks figure prominently in many explanations for aggregate economic fluctuations, ${ }^{13}$ and a handful of previous studies investigate the role of oil price shocks in regional cycles. Barro and Sala-i-Martin (1991), for example, find important effects of oil price shocks on the relative growth rates of per capita gross state product during the 1970s

${ }^{11}$ Bolton (1966), Markusen et al (1991) and Mayer (1991) contain useful descriptions of the subcontracting process and some evidence on the extent and spatial flow of subcontracts. To the best of our knowledge, comprehensive data on subcontracting are not available. ${ }^{12}$ There are nine Census regions: New England (CT, ME, MA, NH, RI, VT), Middle Atlantic (NJ,NY,PA), East North Central (IL,IN,MI,OH,WI) West North Central (IA,KS,MN, MO,NE,ND,SD), South Atlantic (DC, DE, FL, GA, MD,NC,SC,VA,WV), East South Central (AL, KY, MS,TN), West South Central (AR,LA, OK,TX), Mountain (AZ,CO,ID,MT, NM,UT,WY), and Pacific (AK,CA,HI, NV,OR,WA). ${ }^{13}$ See, for example, Hamilton (1983, 1996), Loungani (1986), Davis (1987), Hooker (1996), Davis and Haltiwanger $(1996,1997)$ and the survey by Mork $(1994)$. 
and 1980s. Brown and Hill (1988), Schmidt (1989) and Bauer and Byrne (1991) emphasize that the adverse consequences of an oil price increase are likely to be distributed across states in a highly uneven manner because of differences in their industry composition. ${ }^{14}$

The real price of oil increased dramatically during the OPEC-induced shocks of 197375 and 1979-81, and then declined to nearly its pre-1973 level by 1986 . The decline in crude petroleum prices from 1985 to 1986 was precipitous, qualifying this period as the "third oil shock" of the post-1970 period. As discussed by Hamilton $(1983,1985)$, major movements in the relative price of oil, even in the "pre-OPEC" period, reflected events exogenous to the aggregate economy and certainly to regional economies.

\section{Interaction of oil price shocks and state industry composition}

We hypothesize that the state-level impact of oil price changes depends on its "portfolio" of industries. To capture the interaction between oil shocks and a state's industry mix, we proceed as follows. Let $G E_{i t}$ denote the national growth rate of employment in industry $i$ during year $t$. For this exercise, we use the following ten-industry decomposition: (1) mining (2) construction, (3) transportation, communication and public utilities (TPU), (4) services, (5) finance, insurance and real estate (FIRE), (6) trade, (7) government, (8) primary metals, (9) motor vehicles, and (10) other manufacturing industries. The first seven industries listed are one-digit industry groups outside of manufacturing. The more detailed breakdown of manufacturing reflects our prior view that the response of

${ }^{14}$ Brown and Hill use state input-output tables for 1979 to estimate the impact of the 1986 oil price decline on state employment. Schmidt looks more broadly at the performance of "resource-dependent" states relative to other states using gross state product data for the 1964-86 period. He finds that, on average, resource-dependent states had faster but also more volatile growth over this period. Bauer and Byrne present estimates of the impact of an oil price increase on gross state product. 
manufacturing industries to oil price shocks is likely to exhibit considerable heterogeneity. We considered several key industries that are likely to experience either sharply higher factor costs or sharply lower final goods demand in the wake of an oil price increase. After some experimentation, we chose primary metals (SIC 33) to capture the former effect, and motor vehicles (SIC 371) to capture the latter. ${ }^{15}$

For each industry, we carried out national time-series regressions of the form,

$$
G E_{i t}=\beta_{i}+\delta_{i} C O N B_{t}+\theta_{i 0} O I L R_{t}+\theta_{i 1} O I L R_{t-1}+v_{i t}, \quad i=1,2, \ldots, 10
$$

where $O I L R$ is the growth rate of the relative price of crude petroleum, and $C O N B$ is the change in a particular distributed lag of U.S. defense contract awards. ${ }^{16}$ The coefficients $\theta_{i 0}$, and $\theta_{i 1}$ show the response of national employment growth in industry $i$ to contemporaneous and lagged oil price shocks.

We estimate these regressions using annual U.S. data from 1948 to 1992 . Estimates of the $\theta_{i 0}$ and $\theta_{i 1}$ coefficients exhibit the expected properties. Mining employment increases significantly in response to an increase in oil prices, but the estimated coefficients are negative for other industries, and in most cases significantly different from zero. The estimated impact of oil prices on employment growth is much larger in construction, manufacturing and TPU than in the other four 1-digit industries. Within manufacturing, the impact

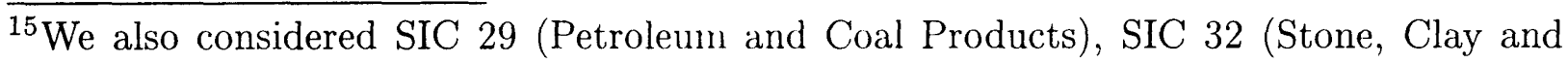
Glass Products) and SIC 35 (Nonelectrical Machinery) to capture the "sharply higher factor costs" effect. These three industries did not add much to the spatial variation in the OIL measure (to be defined shortly) and were dropped from further consideration. ${ }^{16}$ Based on the discussion in Bolton (1966, chapter 5), we compute defense (and NASA) contract expenditures as .6 times contemporaneous contract awards, plus .3 times lagged awards, plus .1 times twice-lagged awards. CONB equals the change in expenditures, so measured. 
on primary metals and motor vehicles is twice as large as for the "other manufacturing" category.

We interact the estimated national responses of industry employment to oil shocks with state-level measures of industry employment shares (denoted by $S_{i s t}$ ) as follows:

$$
O I L_{s t}=-\sum_{i=1}^{10}\left(\theta_{i 0} O I L R_{t}+\theta_{i 1} O I L R_{t-1}\right) S_{i s t}
$$

It is important to note that we construct the time series for $S_{i s t}$ by linear interpolation between decennial Census years. This procedure removes purely cyclical changes in employment shares, while incorporating more slow-moving shifts in state-level industry composition.

We hypothesize that $O I L_{s t}$ covaries positively with state-level unemployment movements. In other words, an oil price increase causes a sharper unemployment rise in states with higher employment shares devoted to industries more adversely affected by an increase in oil prices. Our approach allows for nonstationary responses to oil price changes as the result of secular changes in state-level industry portfolios.

\subsection{Industry mix and nonneutral responses to national business cycles}

The driving forces considered thus far have the advantage that their major movements reflect readily identifiable events, such as wars and pricing decisions by OPEC, that are exogenous to the U.S. business cycle. To the extent that national business cycles are driven by such disturbances, we expect to capture any nonneutral state-level responses to national business cycles using the measures described above. However, military variables and oil price shocks are unlikely to exhaust the list of important driving forces behind national cycles with nonneutral state-level effects. Hence, following Neumann and Topel (1991) and Bartik (1991), we construct an additional explanatory variable to capture differences among states in the sensitivity to national business cycles driven by other "unspecified" 
disturbances. ${ }^{17}$ Specifically, for each state we construct a "predicted" national cycle effect on employment by interacting the national employment growth rate residuals $v_{i t}$ in the regressions (4) with state-level measures of industry employment shares:

$$
M I X_{s t}=\sum_{i=1}^{10} S_{i s t} v_{i t}
$$

This state-specific national cycle variable picks up the effects of the many shocks, such as changes in the stance of monetary policy, that we do not measure directly. We expect $M I X_{s t}$ to covary negatively with state unemployment.

\subsection{Allocative shocks within states}

Previous research indicates that shocks to the industry structure of demand play a role in aggregate unemployment movements because of frictions in the process of reallocating workers to jobs [Lilien (1982), Davis (1987), Davis and Haltiwanger (1990)]. The same logic implies that shocks to the structure of demand within states play a role in state unemployment fluctuations. Lilien measured the impact of such "allocative disturbances" by constructing a measure of the dispersion of employment growth across industries. Loungani, Rush and Tave (1990) and Brainard and Cutler (1993) show that the dispersion of stock returns across industries has more explanatory power for aggregate unemployment. ${ }^{18}$

We implement this idea at the state level by interacting industry stock returns at the

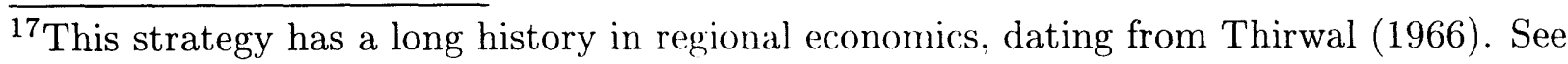
Forrest and Naisbitt (1988).

${ }^{18}$ These studies suggest that stock returns work better, because they are more likely to reflect permanent shocks to industry fortunes. Stock return dispersion measures also overcome certain problems suffered by employment-based dispersion measures, because stock returns respond more immediately and sensitively to news about permanent shocks to the desired allocation of labor and other factors of production. 
national level with state employment shares to obtain a stock market dispersion index for each state. Let $R_{i t}$ denote the stock return for industry $i$ at time $t$, and let $R_{t}$ denote the aggregate stock return. ${ }^{19}$ We compute the weighted dispersion of industry-level excess returns with weights given by state-level employment shares:

$$
S T D I S P_{s t}=\left[\sum_{i=1}^{7} S_{i s t}\left(R_{i t}-R_{t}\right)^{2}\right]^{1 / 2}
$$

We expect $S T D I S P_{s t}$ to covary positively with state-level unemployment.

\section{The effects of the driving forces on unemployment}

\subsection{Basic regressions (Table 2)}

Panel A in Table 2 reports the estimated sum of coefficients on current and lagged values of each independent variable in our baseline unemployment regressions. ${ }^{20}$ The independent variables are scaled by their respective standard deviations, so that the sum gives the estimated current effect of a one standard deviation increase in current and lagged values. All regressions include state and year fixed effects, so that the coefficient sums provide information about the forces driving the regional cycle component of state-level unemployment fluctuations. Panel B reports test statistics for the joint null hypothesis that current and lagged values of an independent variable have no explanatory power.

${ }^{19}$ Industry-level and aggregate returns were constructed as value-weighted log changes in firm-level equity values using CRSP data for seven industry groups: mining, manufacturing, construction, transportation and public utilities, FIRE, services, and trade.

${ }^{20}$ Except for $C O N$ and $M I L$ in the civilian unemployment regressions, lag lengths could be trimmed to two without loss of explanatory power. The longer lags for $C O N$ partly reflect the fact that actual expenditures often lag contract awards; see Bolton (1966). We make a simple adjustment for this lag in calculating the cost of job creation in section 5 . 
Consider the results for the civilian unemployment rate regression. For all five driving forces, the coefficient sums have the anticipated sign, and the null hypothesis of no effect is rejected at conventional significance levels. The estimated response magnitudes for a unit standard deviation shock vary considerably among the driving forces. Oil price shocks have large effects, comparable in size to the combined role of the unspecified shocks captured by the $M I X$ variable. As shown in the table, the sum of coefficients on current and lagged values of $O I L$ is 0.94 percentage points. The coefficient estimates on current and lagged values of $O I L$ and the dependent variable imply a peak unemployment response to a unit standard deviation change in $O I L$ of nearly one percentage point. The other independent variables play smaller roles as driving forces behind regional unemployment fluctuations.

Results for the insured unemployment rate are broadly similar, but the estimated effects of the driving forces are markedly smaller. Of course, the mean and standard deviation of the insured unemployment rate are also markedly smaller. The main difference pertains to the military variables, for which the coefficient sums are small and statistically insignificant. F-test statistics, however, indicate that current and lagged values of $C O N$ and $M I L$ are jointly significant.

\subsection{Evaluating the basic regressions (Tables 3 and 4; Figures 4 and 5)}

Our estimated regressions have the form,

$$
U_{s t}=\gamma_{t}+\alpha_{s}+X_{s t} \beta+\eta_{s t}
$$

where $U_{s t}$ is the unemployment rate in state $s$ at $t, \gamma_{t}$ is a year effect, $\alpha_{s}$ is a state effect, the vector $X_{s t}$ contains all regressors (including lags of the dependent variable), $\beta$ is the estimated coefficient vector, and $\eta_{s t}$ is a residual. Based on (7), we carry out two types of exercises to assess how well the basic regression model explains the regional cycle component of unemployment variation. The first type focuses on the average level 
and time variation of cross-state dispersion in the regional cycle component. The second focuses on time variation in the regional cycle component for individual states. For the sake of brevity, we report the results of these exercises for the civilian unemployment rate only.

We previously defined the regional cycle component as a deviation from state and year fixed effects; i.e., $U_{r, s t}=U_{s t}-\alpha_{s}-\gamma_{t}$. Let $\sigma_{t}$ denote the unweighted standard deviation of the regional cycle component at time $t$ :

$$
\sigma_{t}=\left[\sum_{s=1}^{n}\left(U_{r, s t}-\bar{U}_{r, t}\right)^{2}\right]^{1 / 2}
$$

where $\bar{U}_{r, t}$ denotes the unweighted mean regional cycle component. We refer to $\sigma_{t}$ as the "actual" dispersion of the regional cycle component.

To assess the performance of the model in accounting for the magnitude and time variation of $\sigma_{t}$, define the corresponding "predicted" dispersion,

$$
\sigma_{t}^{p}=\left[\sum_{s=1}^{n}\left(X_{s t} \beta-\overline{X_{t} \beta}\right)^{2}\right]^{1 / 2}
$$

where $\overline{X_{t} \beta}$ equals the unweighted mean of the estimated regional cycle components. Clearly, the behavior of $\sigma_{t}^{p}$ depends on the observed variation in the driving forces and the estimated coefficients. We construct one version of $\sigma_{t}^{p}$ using observed values of the lagged dependent variable and a second "dynamic" version using the model's internally generated predictions. The first version of $\sigma_{t}^{p}$ helps assess the overall adequacy of the model. The second version quantifies the model's capacity to explain unemployment variation in terms of measured driving forces.

Figure 4 displays the time paths of $\sigma_{t}$ and $\sigma_{t}^{p}$, and Table 3 reports related information. The actual dispersion in the regional cycle component of unemployment ranges from a 
standard deviation of less than one percentage point in 1969 to about 2.25 percentage points in 1983. In other words, the degree of spatial dispersion in labor market tightness varies considerably over time. Using observed values of the dependent variable in (9), the predicted dispersion of the regional cycle component closely tracks actual dispersion. Table 3 shows that actual dispersion is moderately larger on average and more variable over time than predicted dispersion. The simple correlation between the two series is .84 .

The dynamic predicted dispersion ranges from a standard deviation of roughly .25 percentage points in several widely scattered years to about .9 percentage points in 1975 and 1987. It averages .47 percentage points, as compared to 1.5 percentage points for actual dispersion. By this metric, our measured driving forces account for about one-third of the average cross-state variation in the regional cycle component of unemployment fluctuations. Figure 4 shows that the dynamic predicted dispersion captures much of the time variation in actual dispersion over the latter half of the sample. Actual and dynamic predicted dispersion rise sharply in the aftermath of the major oil price shocks of 1973-75, 1979-81 and 1986.

The statistics reported in the lower panel of Table 3 help assess the contributions of the five driving forces to movements in $\sigma_{t}^{p}$. We construct $\sigma_{t}^{p}[C O N]$, for example, by zeroing out the estimated coefficients on the other driving forces. Because this calculation ignores covariances, the components of dynamic $\sigma_{t}^{p}$ do not sum to the total. The calculations indicate that all five driving forces make an appreciable contribution to explaining the level and time variability of $\sigma_{t}^{p}$. Oil price shocks are the biggest driving force behind regional unemployment fluctuations in terms of contribution to both the average level of dispersion and its time variation.

To assess the model's ability to explain within-state time variation in the regional cycle component of unemployment, we proceed in an analogous manner. For each state $s$, 
we first calculate a measure of actual volatility in the regional cycle component,

$$
\sigma_{s}=\left[\sum_{t=1}^{T}\left(U_{r, s t}-\bar{U}_{r, s}\right)^{2}\right]^{1 / 2}
$$

and a measure of predicted volatility,

$$
\left.\sigma_{s}^{p}=\left[\sum_{t=1}^{T} X_{s t} \beta-\overline{X_{s} \beta}\right)^{2}\right]^{1 / 2}
$$

The values of $\sigma_{s}$ for the 51 states are shown in Figure 5 by the height of the white portion of the bars. The dark portion of the bar represents $\left[\sigma_{s}^{p}-\sigma_{s}\right]$; that is, a dark bar placed above the white bar indicates over prediction, and a dark bar below the zero line indicates under prediction. The predicted values, $\sigma_{s}^{p}$, are generated using the model's internally generated predictions of the lagged dependent variable. ${ }^{21}$ The figure shows that predicted values of within-state volatility line up well with actual volatility. While there is a tendency to overpredict (40 out of 51 states), the figure does not suggest any discernible pattern to the prediction errors.

Table 4 reports summary statistics for $\sigma_{s}$ and $\sigma_{s}^{p}$ and, as before, includes a lower panel that focuses on the contributions of the individual driving forces. Once again, oil price shocks emerge as the single most important driving force. They are especially important for regional unemployment fluctuations in Midwestern states such as Michigan, Indiana and Ohio. The military variables make small contributions to regional unemployment fluctuations in the "average" state but large contributions in some states. For example, $\sigma_{s}^{p}[C O N]$ is large for Connecticut and Washington, which indicates that prime contract awards have been an important source of unemployment fluctuations in these states. $\sigma_{s}^{p}[M I L]$ is large

${ }^{21}$ When actual values of the lagged dependent variables are used, $\sigma_{s}$ and $\sigma_{s}^{p}$ are very close for almost every state. 
for Alaska, the District of Columbia and Hawaii. Wyoming and New Mexico have been subject to larger than average shocks to the industry structure of demand, judging by their relatively large values for $\sigma_{s}^{p}[S T O C K]$.

\subsection{Spillovers (Table 5)}

Table 5 reports the results of adding regional spillover variables for the contract awards and military personnel variables. To facilitate comparison of spillover and own-state effects, we scale each spillover variable by the standard deviation of the corresponding own-state measure; e.g., $C O N R$ is scaled identically to $C O N$.

Changes in the basing of military personnel generate tiny spillover effects in absolute terms and in comparison to direct own-state effects. The coefficient sums on $M I L R$ are tightly estimated and close to zero in both regressions. The combination of nonneglibible own effects and tiny spillover effects suggests that military basing decisions have important, but highly localized, effects on regional economies.

In contrast, the spillover effects of prime contract awards are large and statistically significant. In the civilian unemployment rate regression, the estimated coefficient sum on $C O N R$ is twice as large as the corresponding sum for the own-state variable, $C O N$. Taken at face value, this finding indicates that per capita military expenditures in surrounding states have a bigger effect than equal per capita own-state expenditures.

This characterization of regional labor market behavior is not completely implausible ${ }^{22}$ but it is well to recall two features of the prime contracts data. First, subcontracts and hence expenditures often flow beyond the boundaries of the prime contractor's state.

${ }^{22}$ If the relevant local labor markets are more closely approximated by Census regions than by U.S. states, then a rest-of-region expenditure measure is closer to the ideal measure than an own-state measure. 
Second, expenditures typically lag somewhat behind contract awards, and there is considerable variation and randomness in the length of lag. Both features introduce error into the $C O N$ and $C O N R$ variables as measures of expenditures, but the measurement error component is probably much smaller in the rest-of-region variable: subcontract awards are more likely to remain within the region than the state, and the random component of the timing lag is more likely to average out at the region level. Thus, we suspect that measurement error underlies the relatively large spillover effects of contract awards, but quantifying the extent and influence of measurment error is a task for another occasion. Regardless of interepretation, Table 5 highlights the dangers of ingnoring regional spillover effects in evaluating the local economic effects of contract awards.

\subsection{Asymmetric effects (Table 6)}

Standard real business cycle models that incorporate a role for oil price shocks [e.g., Kim and Loungani (1992)] predict that the response of real activity to positive and negative oil price shocks is roughly symmetric. In this class of models, oil shocks operate through wealth channels or through substitution effects in an aggregate production function.

Some other research draws a distinction between the "aggregate" and "allocative" channels through which oil shocks affect aggregate activity [e.g., Davis (1986), Loungani (1986), Mork (1989) and Davis and Haltiwanger $(1996,1997)]$. If oil shocks alter the match between the desired and actual distribution of factor inputs, and if there are frictions in the process of reallocating factor inputs to new uses, even a decline in oil prices imparts a negative effect on aggregate output and employment. To the extent that oil shocks influence aggregate activity through allocative as well as aggregate channels, price increases have larger net effects than price declines. We investigate whether asymmetries of this sort are important in Table 6 by allowing negative and positive values of $O I L$ to enter 
separately into the unemployment regressions. Similar arguments can be made for military expenditures, so we also allow $C O N, C O N R$ and $M I L$ to have asymmetric effects.

The evidence in Table 6 supports the type of asymmetry predicted by theories that stress the allocative aspects of oil and military shocks. In the civilian unemployment rate regression, the estimated effects of negative changes in own-state and regional contract awards are nearly twice as large as the effects of positive changes. The asymmetry is even more dramatic for military personnel changes. The estimates for $O I L$ point to a mild asymmetry in the civilian unemployment regression and a sharp asymmetry in the insured unemployment rate regression. The departure from symmetry is consistent with the view that the impact of oil prices on real activity works through a mixture of both "aggregate" and "allocative" channels.

While the evidence in Table 6 favors the asymmetry prediction, the hypothesis test results reported in Panel B reveal that much of the evidence is weak. The hypothesis of equal coefficient sums on positive and negative values is rejected at conventional significance levels only for the military personnel variable in the civilian unemployment regression and for the oil shock variable in the insured unemployment regression. The hypothesis of identical distributed lags on positive and negative values is rejected for the contract spillover variable in both regressions and for the military personnel variable in the civilian unemployment regression.

\section{The joint dynamics of unemployment, employment and participation}

\subsection{A Panel VAR Model with Oil Shocks and Contract Awards}

To investigate the joint dynamics of regional labor market variables, we specify a VAR model that includes $O I L, C O N$, log employment $(E M P)$, the civilian unemployment rate $(U N)$, and the labor force participation rate $(P A R T)$. Essentially, we add the $O I L$ 
and $C O N$ variables to the VAR system considered by Blanchard and Katz (1992). We incoporate regional spillover effects of $C O N$ in a manner spelled out below. In light of our earlier discussion of exogeneity, we identify a structural VAR by imposing the following causal ordering on the reduced-form innovations: (OIL, CON, EMP,UN, PART). Reversing $O I L$ and $C O N$ in the ordering does not affect the results.

We estimate the VAR on panel data for the 51 states over the 1958 to 1992 period. We include two lags of each variable, allow for state and year fixed effects, and impose common slope coefficients across states. Figures A.1 and A.2 in Appendix A display a complete set of impulse response functions corresponding to the estimated VAR and the causal ordering specified above. In the main text, we restrict attention to the response of labor market variables to $O I L$ and $C O N$ impulses. ${ }^{23}$

Figure 6 shows the dynamic response to a unit standard deviation $O I L$ shock. The peak effect on the BLS employment measure is a decline of 0.85 percent after two years; nine years later employment still lies 0.45 percent below its initial level. The peak impact on unemployment is a rise of slightly over 0.2 percentage points one year after the impulse. Unemployment returns to its initial level in six years. The effects on participation are small and persistent. The effects of a negative unit standard deviation shock to $C O N$, shown in Figure 7, are qualitatively similar but smaller in magnitude. The peak response in the BLS employment measure is a 0.42 percent decline two years after the impulse.

These results support the Blanchard-Katz emphasis on the role of migration as the "dominant adjustment mechanism" in response to regional shocks. This inference follows because the sum of participation and unemployment responses is much smaller than the

${ }^{23}$ Estimating an eight-variable VAR model and using the ordering (OIL, CON, MIX, $E M P, U N, P A R T, S T D I S P, M I L)$ yields results similar to the ones described in the text. 
employment response. This pattern is especially pronounced for the longer term response, but even the impact effects are dominated by employment adjustments, suggesting a rapid migration response.

To investigate the sensitivity of these conclusions to the employment measure, we re-estimate the VAR using the CPS employment measure in place of the BLS measure. Figures 8 and 9 display the BLS and CPS employment response functions implied by the two VAR systems. According to Figure 8, the impact effect of an oil price increase on the two employment measures is nearly idential, but the longer term responses differ greatly. In particular, the longer term CPS employment response is about one-half larger than its impact response and about one-half larger than the corresponding longer term BLS employment response. Evidently, longer term migration responses are considerably larger than the initial employment impact, and this additional effect involves employment losses in sectors not covered by the BLS measure.

Figure 9 also illustrates important differences between the impulse response patterns for the BLS and CPS employment measures, but of a quite different nature. The impact effect on CPS employment is virtually zero, and the CPS response function lies everywhere above the BLS response function. This result indicates that the negative BLS employment response to a decline in military contracts is partly offset by employment increases in BLS uncovered sectors. As a corollary, the implied migration responses to military expenditure shocks are smaller than suggested by VAR models that focus on the BLS employment measure.

In summary, Figures 6-9 support the following conclusions. First, most of the impact effects of negative regional shocks show up as declines in the regional cycle component of unemployment and participation rates. That is, the migration of jobs and workers does not occur rapidly enough to immediately dissipate the local unemployment effects of local 
shocks. Second, the longer term imprint of regional shocks largely involves changes in the regional distribution of employment and the work force, rather than persistent differences in the regional cycle component of unemployment and participation rates. The migration of jobs and workers dissipates the local unemployment effects of local shocks within a few years. Third, the longer term employment losses (and migration outflows) induced by negative regional shocks greatly exceed the initial employment losses. In other words, regional shocks impart a certain momentum to regional employment growth that persists for several years. Fourth, apparent responses of the BLS employment measure to oil and military impulses partly reflect effects on the distribution of employment between BLS covered and uncovered sectors.

\subsection{Incorporating regional spillovers into the VAR model}

Section 4 finds large spillover effects of military contract awards on unemployment rates. Motivated by this finding, we introduce spillover effects into our VAR framework and explain how to calculate impulse response functions that account for them. We then apply the expanded VAR model to calculate the cost of creating jobs and reducing unemployment.

The $C O N R$ values are linked to the CON values by a set of linear identities, so we need not expand the dimension of the VAR to accommodate spillovers. Instead, we simply introduce the current and two lags of $C O N R$ on the right side of each regression as an exogenous forcing variable. The main issue is how to appropriately calculate impulse response functions for military expenditures. In discussing this matter, it will be convenient to alter notation slightly as indicated below.

Let $P O P\left(R \mid s^{\prime}\right)$ and $D E F\left(R \mid s^{\prime}\right)$ denote population and real contract awards, respectively, in region $R$, less the corresponding value for state $s^{\prime}$. Then, assuming that yearto-year population changes are small, we can approximate $C O N R$ for state $s^{\prime}$ at $t$ as 
follows:

$$
\begin{aligned}
C O N R_{t}\left(s^{\prime}\right)= & \Delta\left[\frac{D E F_{t}\left(R \mid s^{\prime}\right)}{P O P_{t}\left(R \mid s^{\prime}\right)}\right] \\
\approx & \Delta\left[\frac{D E F_{t}\left(R \mid s^{\prime}, s\right)}{P O P_{t}\left(R \mid s^{\prime}\right)}\right]+\Delta\left[\frac{D E F_{t}(s)}{P O P_{t}(s)} \frac{P O P_{t}(s)}{P O P_{t}\left(R \mid s^{\prime}\right)}\right] \\
\approx & \Delta\left[\frac{D E F_{t}\left(R \mid s^{\prime}, s\right)}{P O P_{t}\left(R \mid s^{\prime}\right)}\right]+\frac{D E F_{t}(s)}{P O P_{t}(s)} \Delta\left[\frac{P O P_{t}(s)}{P O P_{t}\left(R \mid s^{\prime}\right)}\right] \\
& +\left[\frac{P O P_{t}(s)}{P O P_{t}\left(R \mid s^{\prime}\right)}\right] \operatorname{CON}_{t}(s)
\end{aligned}
$$

Hence, the impact of an impulse to $C O N_{t}(s)$ on $C O N R_{t}\left(s^{\prime}\right)$ equals the coefficient $\left[\operatorname{POP}_{t}(s) / P O P_{t}\left(R \mid s^{\prime}\right)\right]$. (This coefficient is invariant to the size of the $C O N$ impulse under the approximations used in (12).) Summing over $s^{\prime} \in R, s^{\prime} \neq s$, delivers

$$
\operatorname{POP}_{t}(s) \sum_{s^{\prime} \neq s}\left[1 / P O P_{t}\left(R \mid s^{\prime}\right)\right]
$$

Taking the average of this expression for the states in the region gives

$$
S P I L L_{t}(R)=\frac{1}{R} \sum_{s \in R} \operatorname{POP}_{t}(s) \sum_{s^{\prime} \neq s}\left[1 / \operatorname{POP}_{t}\left(R \mid s^{\prime}\right)\right]
$$

Thus, to capture spillover effects in the VAR impulse response analysis, we shock the $C O N R$ term by SPILL times the size of the CON impulse. To capture the combined effects of own-state and spillover effects, we simultaneously introduce a unit $C O N$ shock and a $C O N R$ shock of SPILL units.

According to (13), we have potentially different time-varying values of $S P I L L_{t}(R)$ for each region. However, simple algebra shows that equal-sized states within a region implies $S P I L L=1$. We maintain this value for $S P I L L$ in our cost-of-job calculations below. 


\subsection{Military spending and the cost of jobs}

Recent studies by government agencies, congressional coalitions and private research organizations reach vastly different conclusions about the regional and economywide implications of the post-Cold War defense cutbacks. In her study based on county-level data, Guthrie (1993) estimates that a $\$ 1$ million decline in prime contract awards lowers employment by 9 to 50 workers. ${ }^{24}$

We use our unemployment regression and VAR models to estimate the cost, in terms of national government purchases from local firms, of creating local jobs and reducing local unemployment. We express these costs in present value terms using annual discount rates of 3,5 and 10 percent. ${ }^{25}$ The resulting calculations deliver estimates of the present value cost of creating one job-year and of reducing unemployment by one person-year.

Table 7 reports the results. When the BLS employment measure is used, the estimates indicate that, depending on the discount rate used, saving one job requires defense contract awards of $\$ 59,030$ to $\$ 92,297$ [column (2)]. As discussed earlier, the impact of defense spending on employment is smaller when the CPS measure is used; this translates into a range of cost-per-job estimates of $\$ 166,259$ to $\$ 201,653$ [column (3)].

Our regression results also point to considerable spillover effects from military contract awards to adjoining states in the Census division. ${ }^{26}$ Hence, an additional dollar in defense

${ }^{24}$ Other studies include the Committee for Economic Development (1991), the NortheastMidwest Congressional Coalition (1991), the Congressional Budget Office (1992), and Schmidt and Kosiak (1992).

${ }^{25}$ To adjust for the lag of expenditures relative to contract awards, we multiply the raw job cost estimates by $.6+[.3 /(1+r)]+\left[.1 /(1+r)^{2}\right]$, where $r$ is the discount rate. This adjustment is in line with Bolton's (1966) discussion and reduces the cost estimates by 1.5 to 4.5 percent.

${ }^{26}$ Our reported results are for unemployment rates, but significant spillover effects arise 
spending to a state creates jobs not only in that state but in adjoining states in the census division. If the job creation in other states is taken into account, the cost-per-job estimates decline markedly. Our VAR model with spillover effects implies that it costs an estimated 34,000 to 56,0001982 dollars to buy one job-year in the BLS covered sector.

\section{Conclusions}

The story behind regional labor market fluctuations in the postwar U.S. economy has a large cast of players: oil price shocks, military contract awards, the basing of military personnel, other national shocks with uneven effects among regions, other shocks that influence the cross-industry dispersion of demand within regions - all play important roles in at least some episodes or certain aspects of the story. But, since the early 1970s, oil price shocks have been the leading actor in the story - the most important driving force behind region-specific fluctuations in unemployment rates and employment growth.

Beyond the magnitude and abruptness of oil price movements, the explanation for their pronounced regional cycle effects has three essential elements: (i) regions differ in industry mix, (ii) industries differ in sensitivity to movements in the relative price of oil, and (iii) the reallocation of productive factors across industries and regions is costly and time consuming. For example, Michigan and Indiana - states with a large concentration of employment in Transportation Equipment and Primary Metals - experience relatively high (low) unemployment rates in the aftermath of an oil price increase (decrease). This regional unemployment response tends to persist for several years. The dominant equilibrating mechansim that brings regional unemployment rates back into alignment is the net migration of people and workers between states.

Oil shocks affect the spatial structure of factor demand through their impact on the

for employent as well. 
industry structure of demand. Some other events operate more directly on the spatial structure of demand. In this regard, we document clear roles for military contract awards and the basing of military personnel. Military basing decisions play a relatively important role as driving forces behind unemployment fluctuations in Alaska, Hawaii and the District of Columbia. Contract awards play a relatively important role in Delaware, Connecticut and Washington. Our preferred estimates, which account for spillover effects across state boundaries, imply a cost of local job creation (through national government purchases from local firms) equal to 34 to 56 thousand 1982 dollars per job-year based on BLS employment figures and about twice as much based on CPS employment figures. The cost of local unemployment reductions are an order of magnitude larger.

The story of regional labor market fluctuations contains important clues about the nature of aggregate business cycle fluctuations. We mention two. First, the spatial dispersion in labor market tightness varies notably over time. Between 1959 and 1992, the cross-state standard deviation of civilian unemployment rates (conditioning out state and year fixed effects) ranges from 0.8 to 2.3 percentage points. This measure of dispersion in the regional cycle component of state unemployment rates displays a clear pattern of countercyclical movements in relationship to the national business cycle. Our regression models account for much of the cyclical variation in the spatial dispersion of labor market tightness since 1973, primarily through the estimated effects of oil shocks.

Second, we find asymmetric unemployment responses to positive and negative regional shocks. Negative shocks - whether involving oil prices, military basing or contract awards have a greater effect than equal-sized positive shocks. This evidence implies that shocks to the spatial structure of demand (e.g., a reallocation of government contract awards) cause short-run increases in aggregate unemployment. Our evidence of asymmetry is similar to Hooker and Knetter's (1996) finding that declines in military contract awards cause 
larger responses in state-level employment than equal-sized increases. The evidence of asymmetry in studies of regional fluctuations is complementary to findings of aymmetric aggregate responses to oil price ups and downs in Mork (1989), Hamilton (1996), Hooker (1996) and Davis and Haltiwanger (1996,1997). 


\section{References}

Asdrubali, Pierfederico, Bent E. Sorensen and Oved Yosha (1996) "Channels of Interstate Risksharing: US 1963-1990." Quarterly Journal of Economics, 111, no. 4, 1081-1110.

Barro, Robert J. and Xavier Sala-i-Martin (1991) "Convergence Across States and Regions" Brookings Papers on Economic Activity, no. 1, 107-182.

Barro, Robert J. and Xavier Sala-i-Martin (1992). "Convergence," Journal of Political Economy, 100, no. 2 (April), 223-251.

Bartik, Timothy J. (1991) Who benefits from state and local economic development policies? W.E. Upjohn Institute for Employment Research. Kalamazoo, Michigan.

Bauer, Paul W. and Susan M. Byrne (1991). "The sectoral and regional effects of oil shocks: who's over a barrel?" Economic Commentary, Federal Reserve Bank of Cleveland, July 15, 1991.

Blanchard, Olivier and Lawrence F. Katz (1992). "Regional evolutions" Brookings Papers on Economic Activity, no. 1, 1-61.

Blank, Rebecca and David Card (1989) "Recent Trends in Insured and Uninsured Unemployment During the 1980's," Industrial Relations Section, Princeton University.

Bolton, Roger (1966). Defense purchases and regional growth. The Brookings Institution. Washington, D.C.

Borjas, George J. and Valerie A. Ramey (1995) "Foreign Competition, Market Power, and Wage Inequality," Quarterly Journal of Economics, 110, no. 4 (November), 1075-1110.

Brainard, S. Lael and David M. Cutler (1993) "Sectoral Shifts and Cyclical Unemployment Reconsidered," Quarterly Journal of Economics, 108, no. 1, 219-243.

Brown, S.P.A. and John K. Hill (1988). "Lower oil prices and state unemployment" Contemporary Policy Issues, VI, July 1988, 60-68.

Burtless, Gary (1983). "Why is insured unemployment so low?" Brookings Papers on Economic Activity, no. 1, 225-249.

Committee for Economic Development (1991) "The Economy and National Defense: Adjusting to Military Cutbacks in the Post-Cold War Era,"

Congressional Budget Office (1992) "The Economic Effects of Reduced Defense Spending," Washington, DC. 
Crump, Jeffrey R. (1989) "The Spatial Distribution of Military Spending in the United States 1941-1985," Growth and Change, Summer, 50-62.

Davis, Steven J. (1986) Allocative Disturbances, Aggregate Disturbances, and Unemployment Rate Fluctuations, Brown University Ph.D. Dissertation.

Davis, Steven J. (1987) "Fluctuations in the Pace of Labor Reallocation," CarnegieRochester Conference Series on Public Policy, 27, 335-402.

Davis, Steve J. and John Haltiwanger (1990) "Gross Job Creation and Destruction: Microeconomic Evidence and Macroeconomic Implications," NBER Macroeconomics Annual, 5, 123-168.

Davis, Steven J. and John Haltiwanger (1996) "Driving Forces and Employment Fluctuations," NBER working paper no. 5775 .

Davis, Steven J. and John Haltiwanger (1997) "Sectoral Job Creation and Destruction Responses to Oil Price Changes and Other Shocks," working paper, University of Chicago.

Davis, Steven J., John Haltiwanger and Scott Schuh (1996) Job Creation and Destruction. Cambridge, Massachusetts: MIT Press.

DiPasquale, Denise and William C. Wheaton (1996) Urban Economics and Real Estate Markets. Englewood Cliffs, New Jersey: Prentice Hall.

Eberts, Randall W. and Joe A. Stone (1992). Wage and employment adjustment in local labor markets, W.E. Upjohn Institute for Employment Research. Kalamazoo, Michigan.

Eichengreen, Barry (1990) "Currency Union," Economic Policy (April 1990), 118-187.

Forrest, D. and B. Naisbitt (1988) "The Cyclical Sensitivity of Regional Unemployment and Unemployment Differentials," Regional Studies, 22, 149-153.

Green, Gloria (1971) "Measuring Total and State Insured Unemployment," Monthly Labor Review (June), 37-48.

Guthrie, Susan (1993) "Defense spending and employment: evidence from regional data," Harvard University working paper.

Hamilton, James, (1983) "Oil and the Macroeconomy since World War II," Journal of Political Economy, 91, 221-248.

Hamilton, James (1985) "Historical Causes of Postwar Oil Shocks and Recessions," 
Energy Journal, 6, 97-116.

Hamilton, James D. (1996) "This Is What Happened to the Oil Price - Macroeconomy Relationship," Journal of Monetary Economics, 38, no. 2 (October), 215-220.

Hooker, Mark (1996) "What Happened to the Oil Price - Macroeconomy Relationship?" Journal of Monetary Economics, 38, no. 2 (October), 195-213.

Hooker, Mark and Michael M. Knetter (1996) "The Effects of Military Spending on Economic Activity: Evidence from State Procurement Spending," Working Paper, Dartmouth College, June.

Lilien, David (1982) "Sectoral Shifts and Cyclical Unemployment," Journal of Political Economy, 90, 777-793.

Loungani, Prakash (1986). "Oil price shocks and the dispersion hypothesis," Review of Economics and Statistics, (August), 536-39.

Loungani, Prakash, Mark Rush and William Tave (1990) "Stock Market Dispersion and Unemployment," Journal of Monetary Economics, 25, no. 3, 367-388.

Markusen, Ann, Peter Hall, Scott Campbell and Sabina Deitrick (1991) The Rise of the Gunbelt: The Military Remapping of Industrial America. New York: Oxford University Press.

Mayer, Kenneth R. (1991) The Political Economy of Defense Contracting. New Haven: Yale University Press.

Mork, Knut A. (1989) "Oil and the Macroeconomy When Prices Go Up and Down: An Extension of Hamilton's Results," Journal of Political Economy, 97, no. 3 (June), 740-744.

Mork, Knut (1994) "Business Cycles and Oil Markets," The Energy Journal, 15 (special issue), 15-38.

Marston, Stephen T. (1985) "Two Views of the Geographic Distribution of Unemployment," Quarterly Journal of Economics, 100, no. 1, 57-79.

Mehay, Stpehen and Loren Solnick (1990) "Defense spending and state economic growth," Journal of Regional Science, 30, no. 4, 477-487.

Neumann, George and Robert Topel (1992) "Employment Risk, Diversification, and Unemployment," Quarterly Journal of Economics, 
Northeast-Midwest Congressional Coalition (1991) "Defenseless: Declining Dollars for the Northeast-Midwest Region," July.

Schmidt, Conrad P. and Steven Kosiak (1992) "Potential Impact of Defense Spending Reduction on the Defense Industrial Labor Force by State," Defense Budget Project, March.

Schmidt, Ronald H. (1989). "Natural resources and regional growth," Economic Review, Federal Reserve Bank of San Francisco (Fall), 3-19.

Thirwall, A.P. (1966) "Regional Unemployment as a Cyclical Phenomenon," Scottish Journal of Political Economy, 13, 205-219.

Topel, Robert H. and Sherwin Rosen (1988) "Housing Investment in the United States," Journal of Politcal Economy, 96, no. 4, (August), 718-740.

Topel, Robert H. (1994) "Wage Inequality and Regional Labor Market Performance in the U.S" in Labor Markets and Economic Performance: Europe, Japan, and the USA, edited by Toshiaki Tachibanaki. New York: St. Martin's Press.

Vroman, Wayne (1991) "The Decline in Unemployment Insurance Claims Activity in the 1980's," unpublished.

Wegner, Merrill (1991) "Defenseless: Declining Military Dollars for the NortheastMidwest Region" Northeast-Midwest Congressional Coalition, July. 

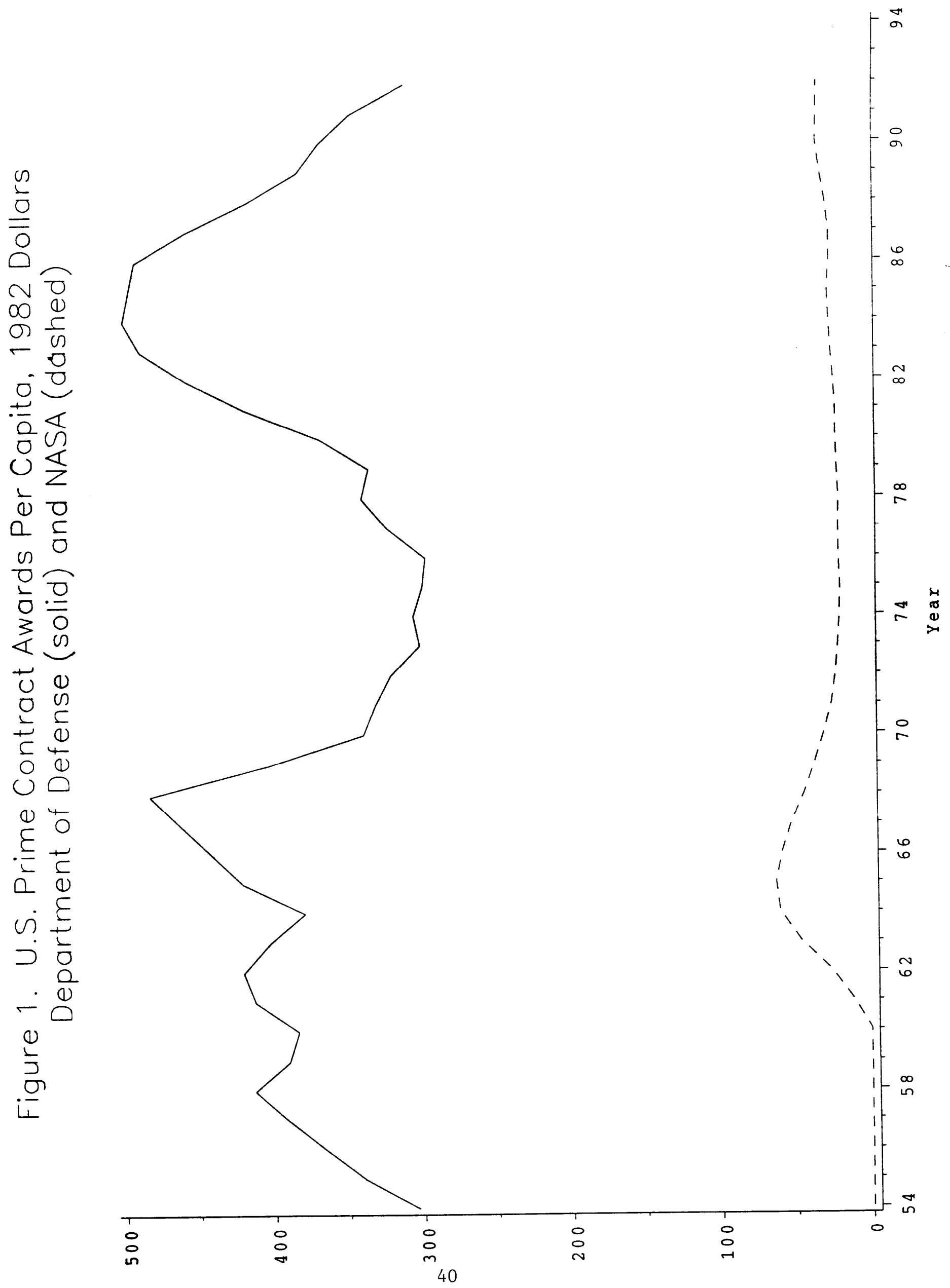


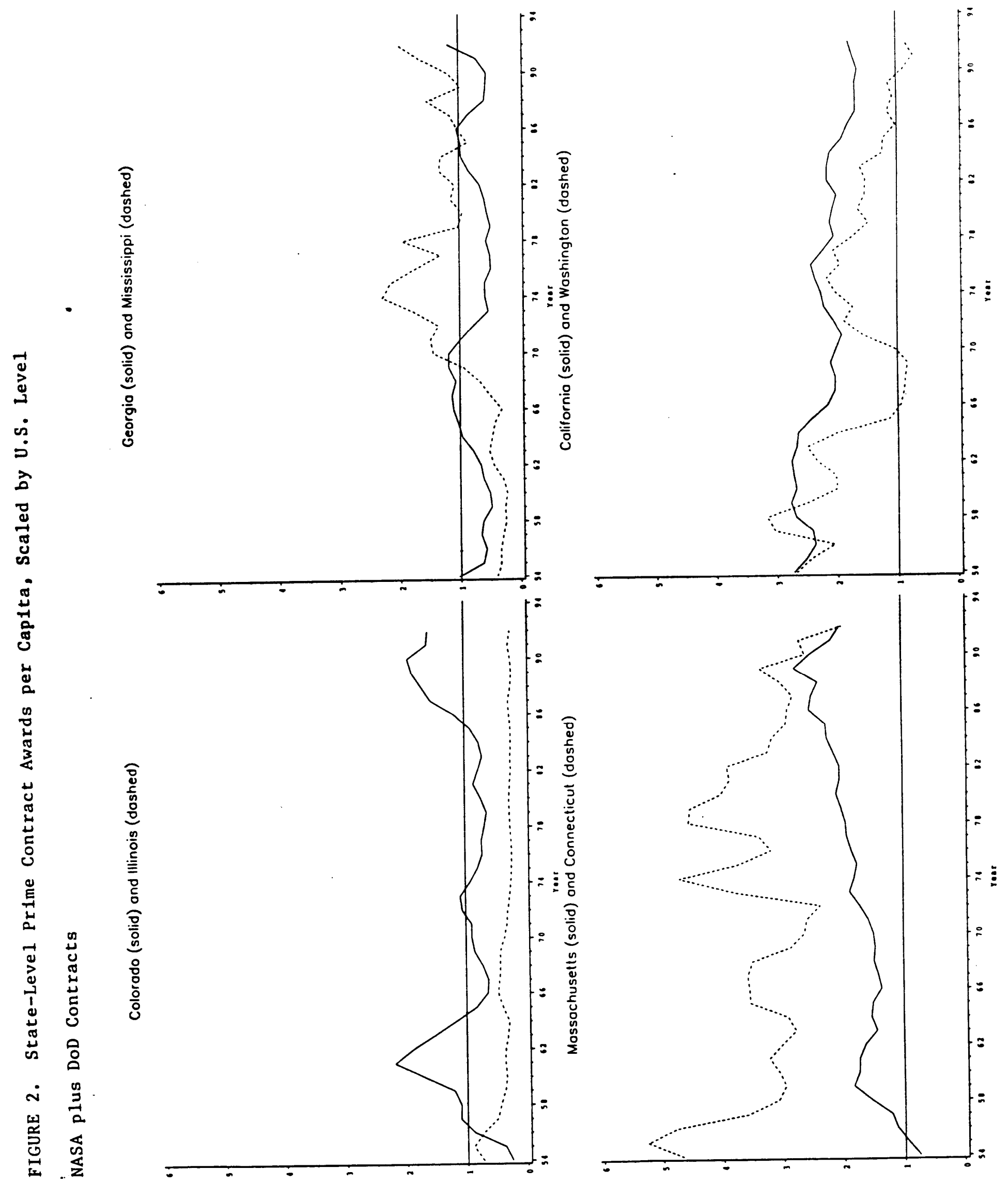




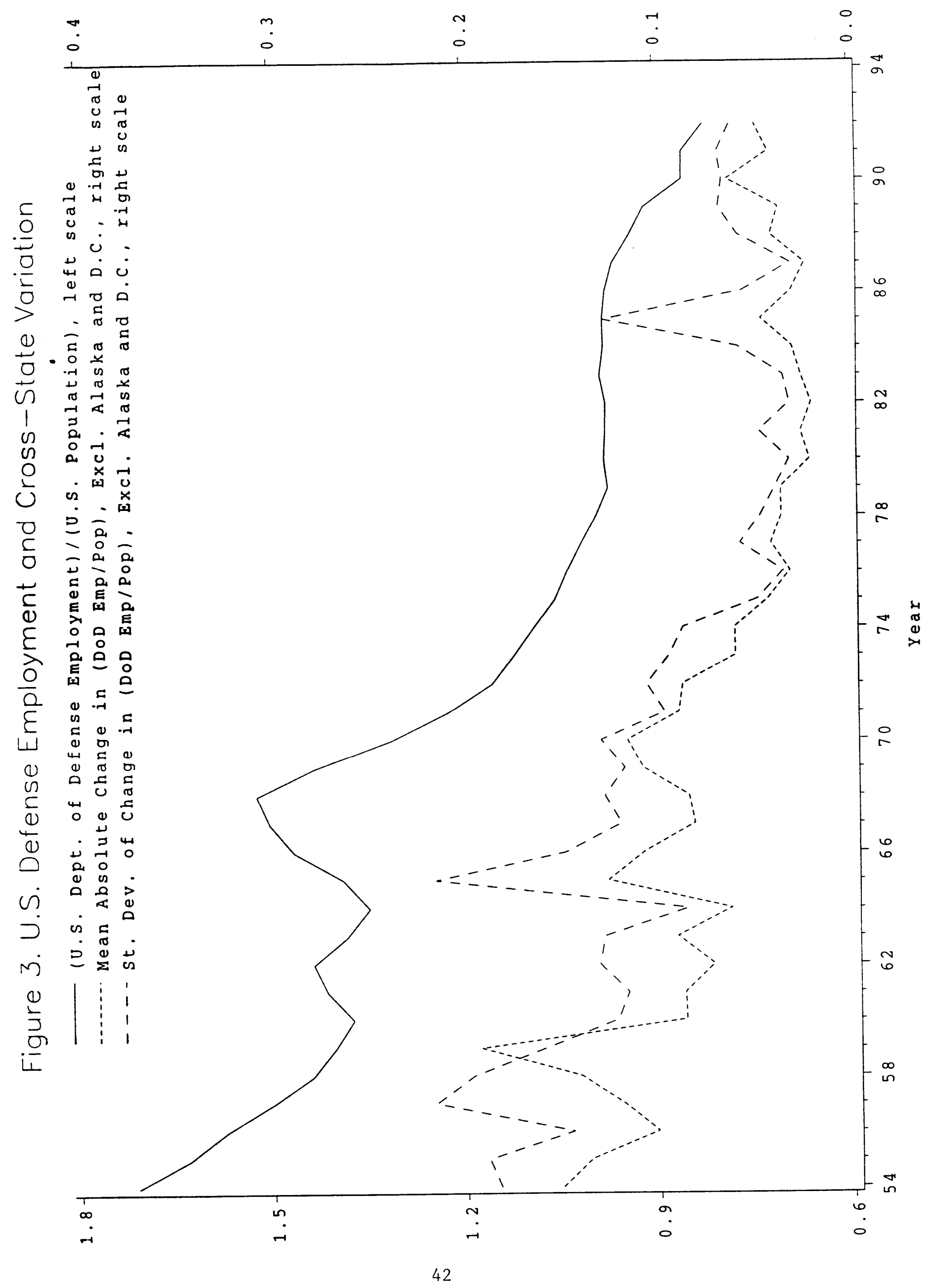




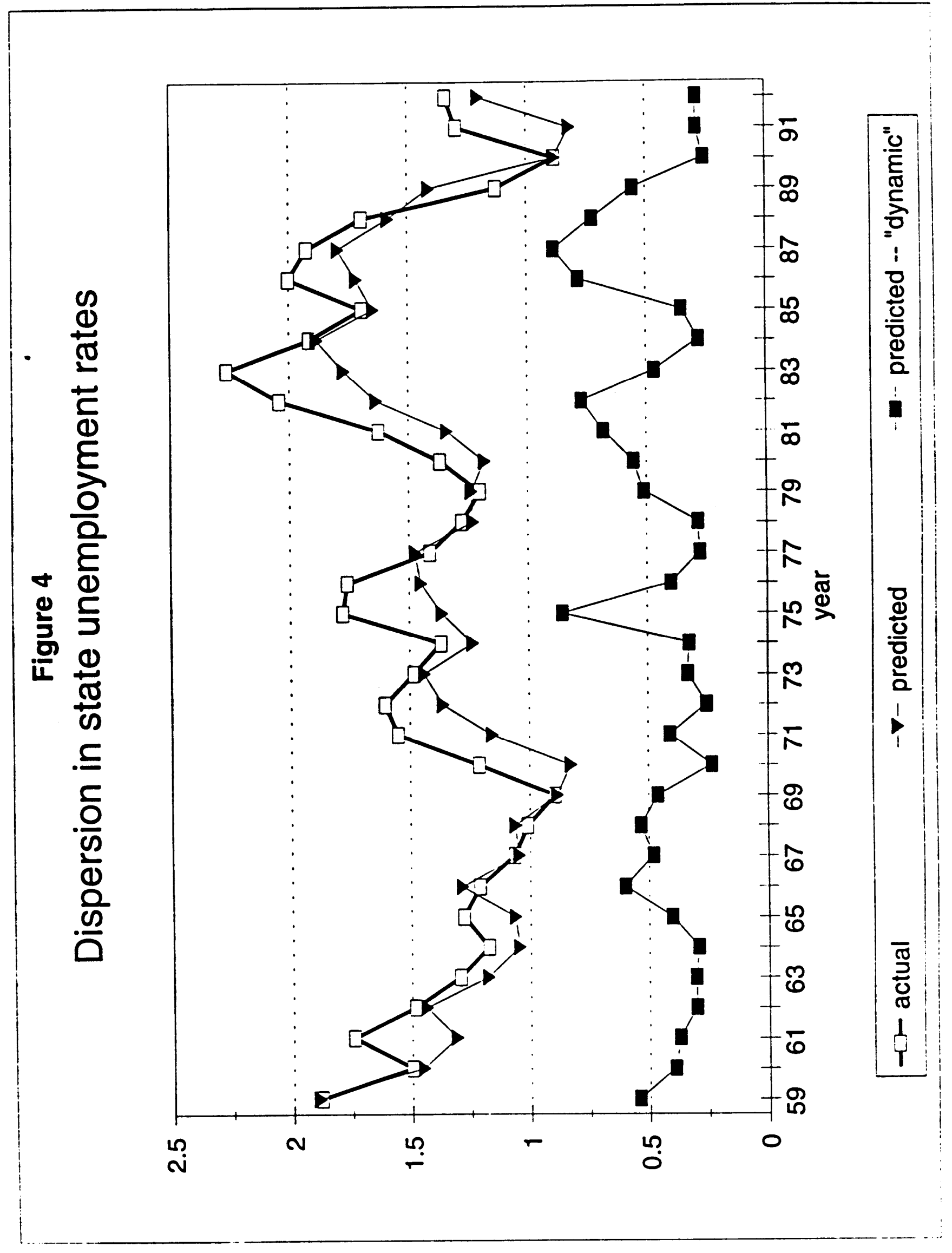




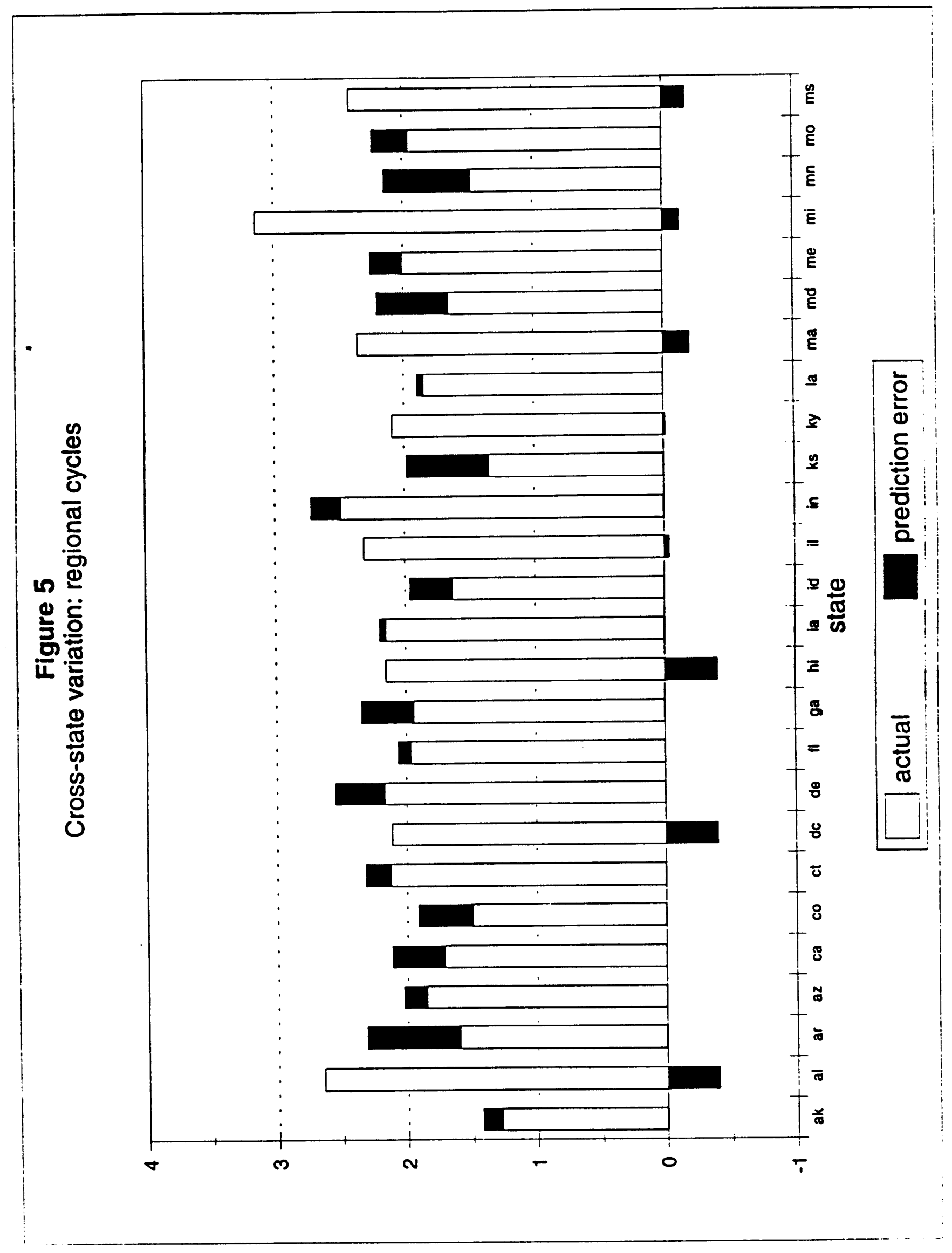




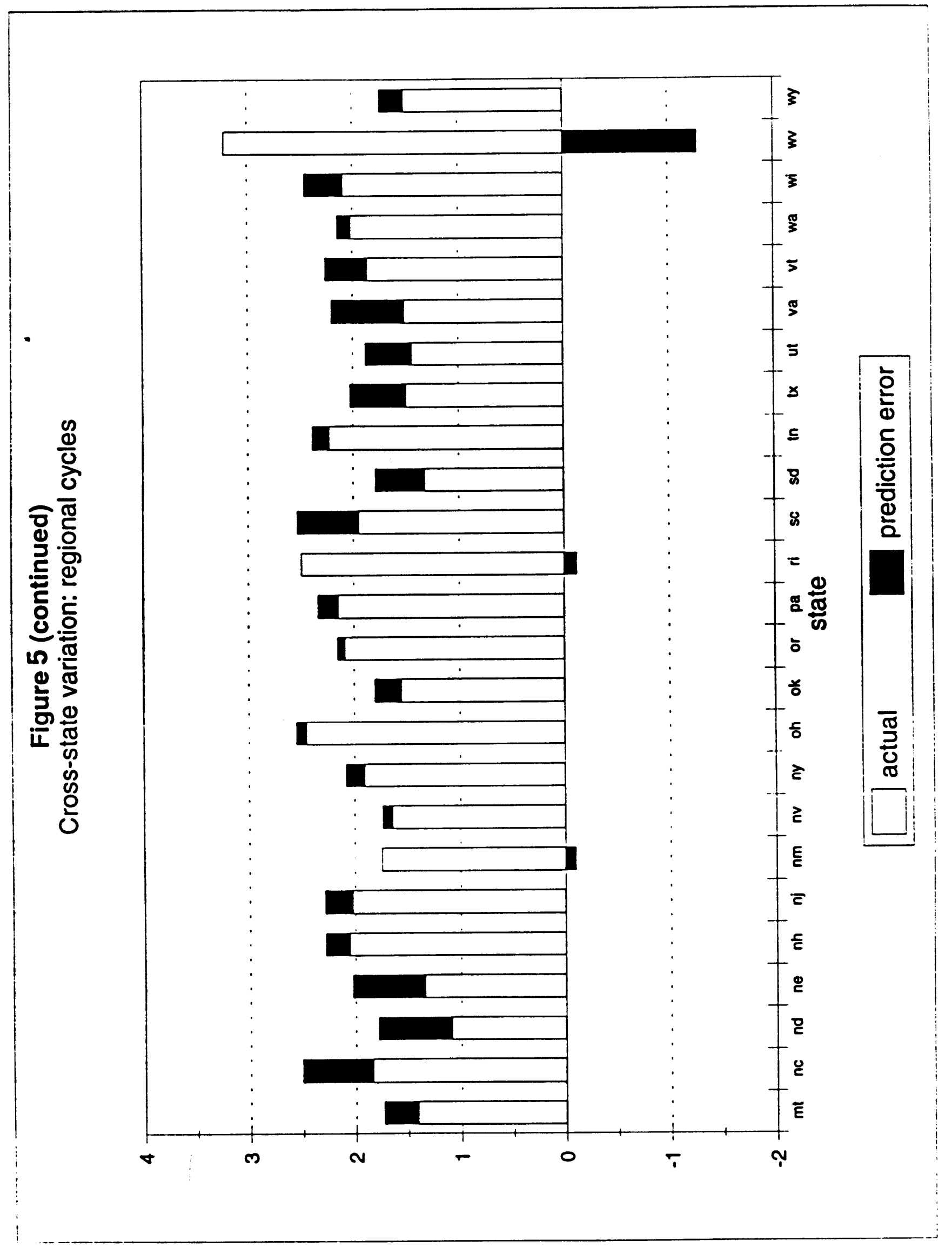


Figure 6

\section{Employment, Unemployment, Participation} response to an oil price increase

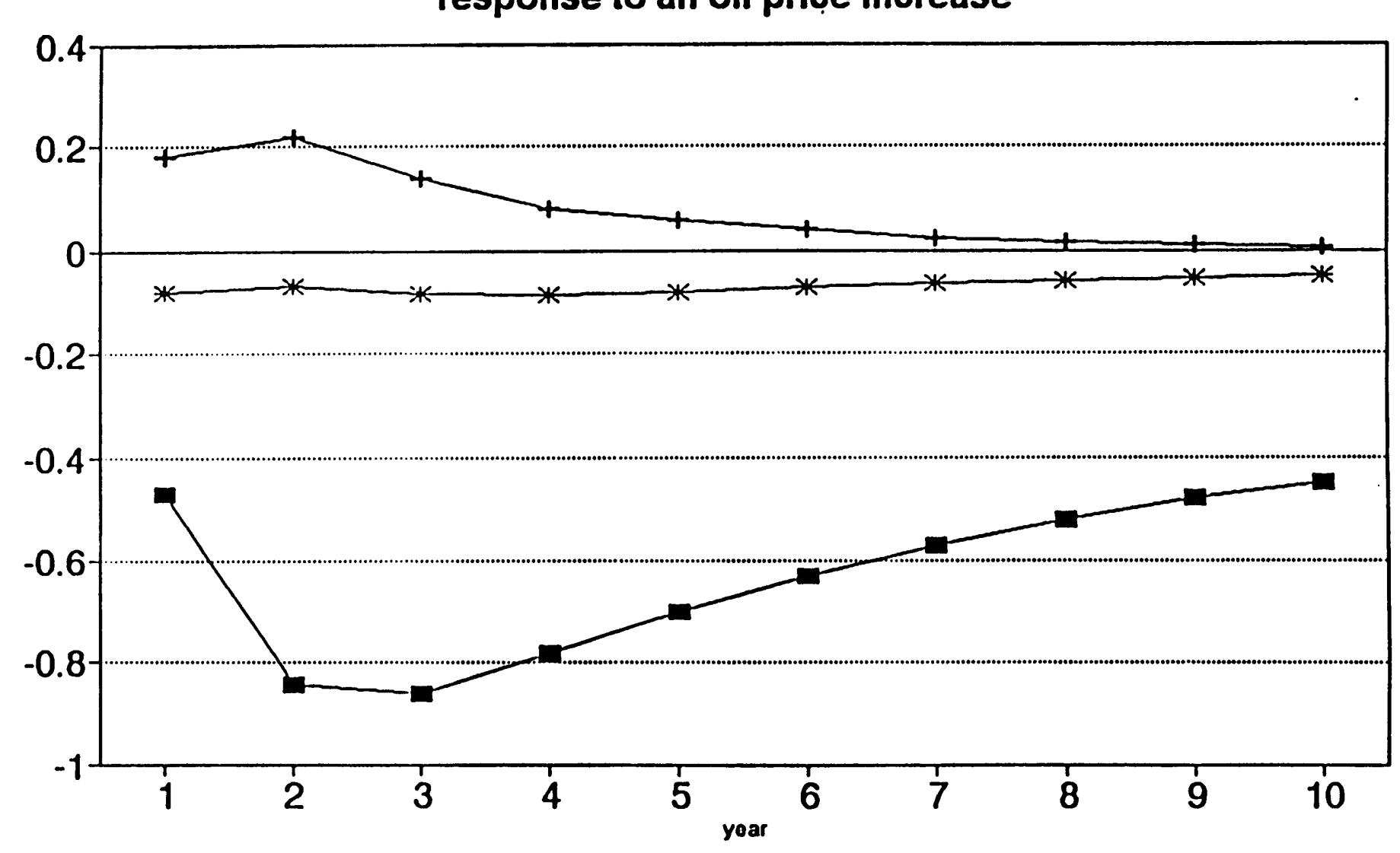




\section{Eigure 7}

\section{Employment, Unemployment, Participation}

response to a fall in defense contracts

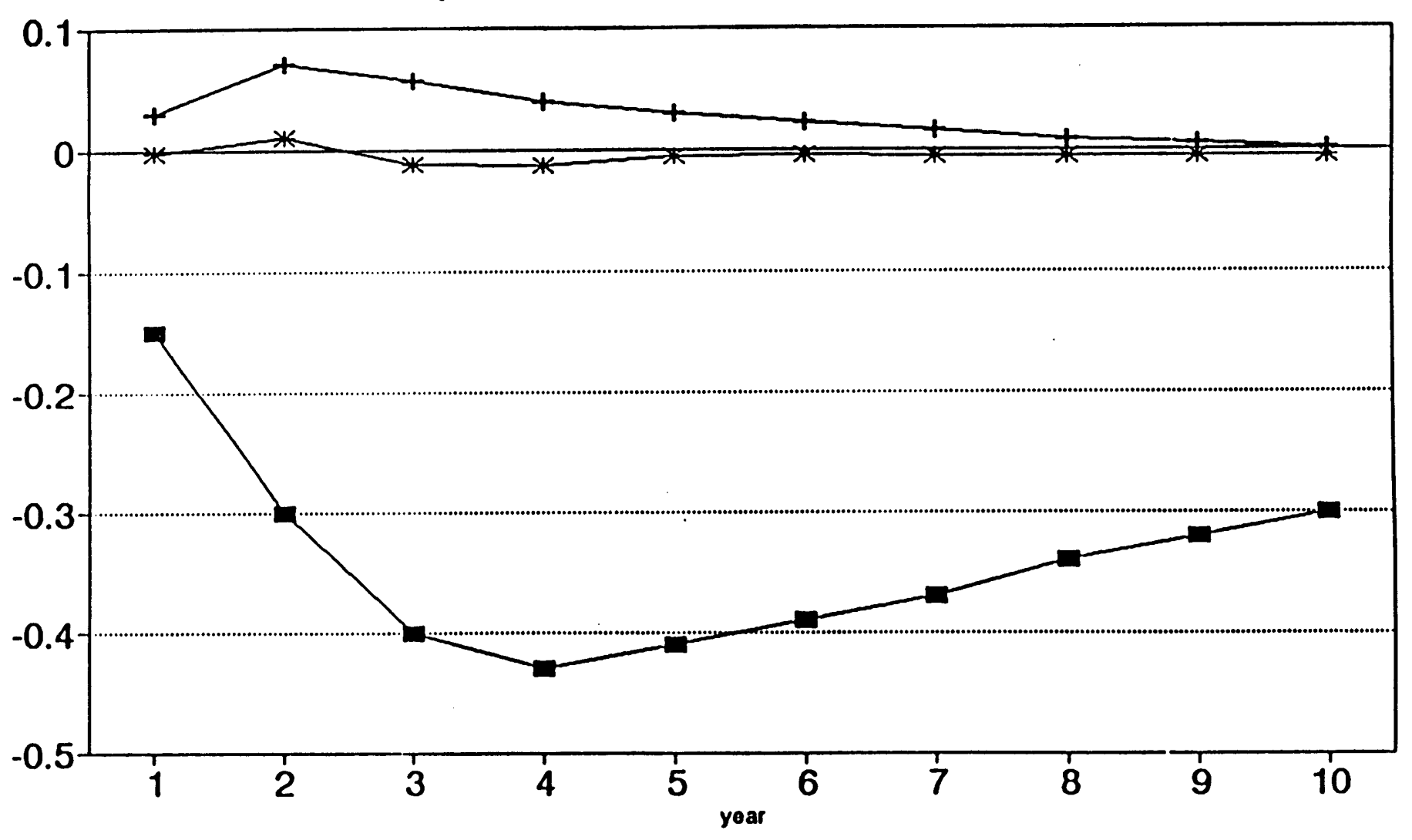

omployment + unomploymont rato $*$ participation rate 


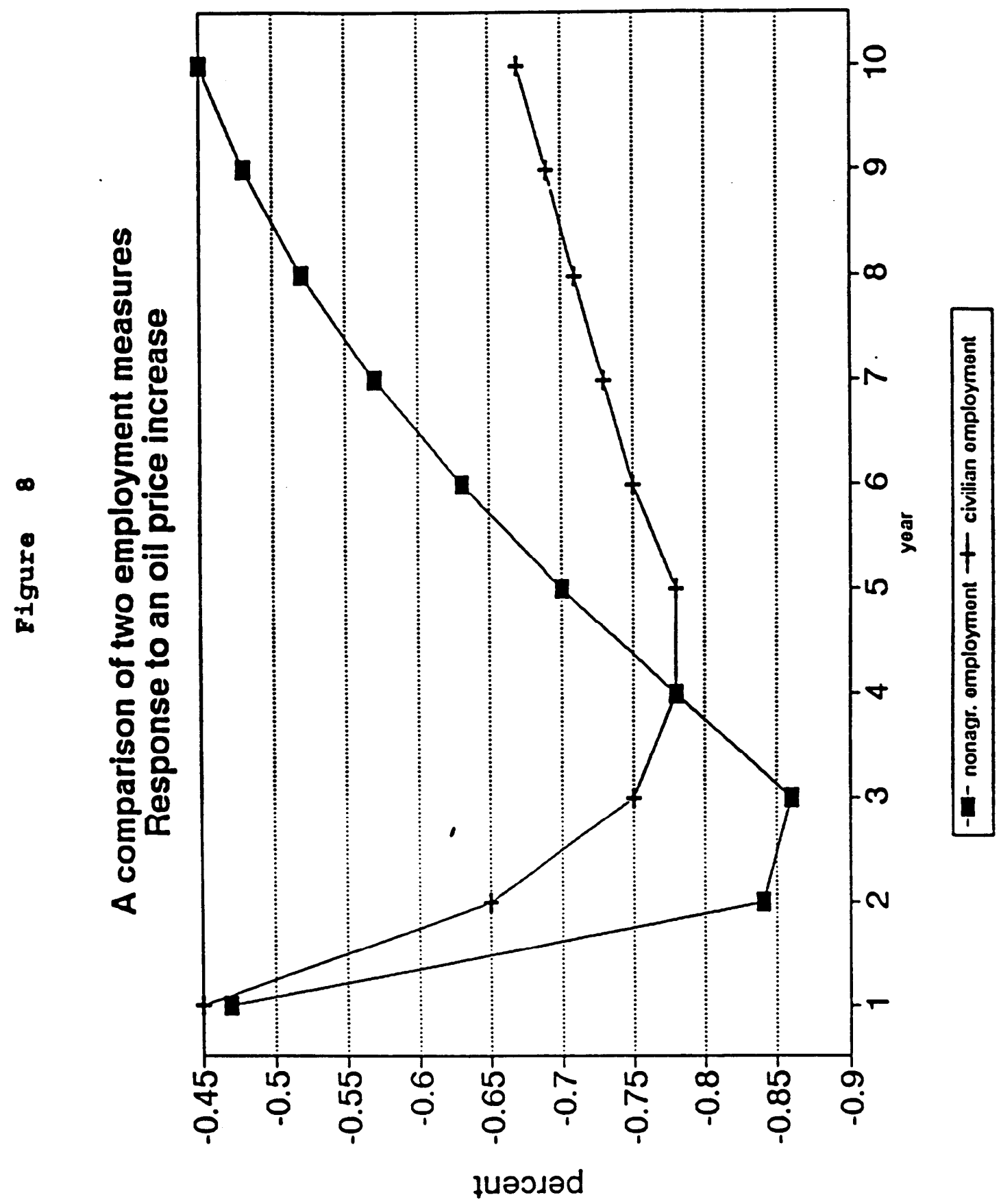


Figure 9

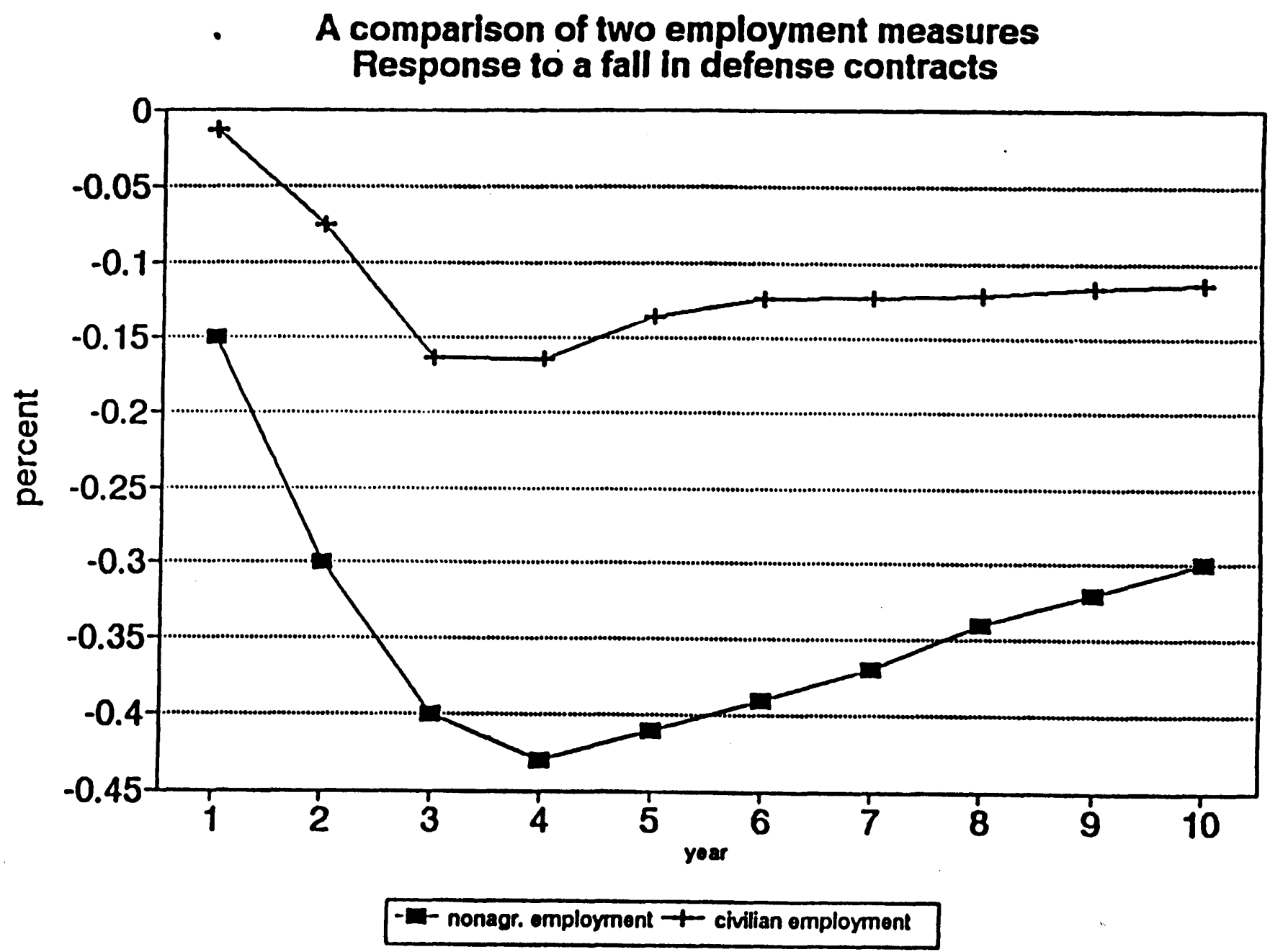


Table 1. Variance components model

$$
\begin{gathered}
U_{s t}=\alpha_{s}+\gamma_{t}+\varepsilon_{s t} \\
\varepsilon_{s t}=\rho \varepsilon_{s t-1}+\eta_{s t}
\end{gathered}
$$

\begin{tabular}{|c|c|c|c|c|}
\hline & (1) & (2) & (3) & (4) \\
\hline Dependent variable & $\begin{array}{c}\text { Civilian } \\
\text { unemployment } \\
\text { rate } \\
(1958 \text { to 1992) } \\
\end{array}$ & $\begin{array}{c}\text { Insured } \\
\text { unemployment } \\
\text { rate } \\
\text { (1949 to1992) } \\
\end{array}$ & $\begin{array}{l}\text { (BLS Emp./Pop.) } \times 100 \\
\text { (1958 to 1992) }\end{array}$ & $\begin{array}{c}\text { (CPS Emp./Pop.) } X 100 \\
\text { (1958 to 1992) }\end{array}$ \\
\hline Mean of dependent variable & 5.96 & 3.50 & 36.76 & 41.16 \\
\hline $\begin{array}{l}\sigma_{u} \\
\text { standard deviation of dep. variable }\end{array}$ & 2.21 & 1.73 & 9.70 & 5.24 \\
\hline $\begin{array}{l}\sigma_{\alpha} \\
\text { standard deviation of state fixed effects }\end{array}$ & 1.38 & 1.16 & 13.27 & 2.87 \\
\hline $\begin{array}{l}\sigma_{\gamma} \\
\text { standard deviation of year fixed effects }\end{array}$ & 1.44 & 1.06 & 1.61 & 3.19 \\
\hline $\begin{array}{l}\sigma_{\epsilon} \\
\text { standard deviation of regional cycle } \\
\text { component }\end{array}$ & 1.86 & 1.34 & 9.90 & 2.93 \\
\hline $\begin{array}{l}\sigma_{\eta} \\
\text { standard deviation of innovation }\end{array}$ & .82 & .62 & .70 & .79 \\
\hline$\sigma_{\alpha}^{2} / \sigma_{u}^{2}$ & 0.39 & 0.45 & 1.87 & .30 \\
\hline$\sigma_{\gamma}{ }^{2} / \sigma_{u}{ }^{2}$ & 0.43 & 0.37 & .03 & .37 \\
\hline$\sigma_{\epsilon}{ }^{2} / \sigma_{u}{ }^{2}$ & 0.71 & 0.60 & 1.04 & .31 \\
\hline $\begin{array}{l}\rho \\
\text { (std. error) }\end{array}$ & $\begin{array}{l}0.70 \\
(0.02)\end{array}$ & $\begin{array}{c}0.69 \\
(0.02)\end{array}$ & $\begin{array}{l}0.97 \\
(.01) \\
\end{array}$ & $\begin{array}{r}.87 \\
(.01) \\
\end{array}$ \\
\hline $\mathrm{R}^{2}$ & 0.86 & 0.87 & .994 & .977 \\
\hline$R^{2}(\rho=0)$ & 0.72 & 0.76 & .95 & .91 \\
\hline
\end{tabular}

Notes to Table 1: The variance components model is estimated by unweighted non-linear least squares on the pooled timeseries cross-state data set. The last row reports the goodness-of-fit measure from an OLS regression that constrains $\rho$ to zero. All statistics are computed on an unweighted basis. 
Table 2: Unemployment rate regressions

\begin{tabular}{|c|c|c|}
\hline $\begin{array}{l}\text { Panel A: Sums of Estimated Coefficents } \\
\text { (standard errors in parentheses) }\end{array}$ & (1) & (2) \\
\hline Dependent Variable & $\begin{array}{l}\text { civilian } \\
\text { unemployment }\end{array}$ & $\begin{array}{c}\text { insured } \\
\text { unemployment }\end{array}$ \\
\hline First lag of dependent variable & $\begin{array}{r}0.86^{* * *} \\
(0.02)\end{array}$ & $\begin{array}{r}0.80^{* * *} \\
(0.02)\end{array}$ \\
\hline Second lag of dependent variable & $\begin{array}{r}-0.12^{* * *} \\
(0.02)\end{array}$ & $\begin{array}{r}-0.06^{* * *} \\
(0.02)\end{array}$ \\
\hline $\begin{array}{l}\operatorname{CON}\{0 \text { to } 5\} \\
\text { change in state-level real, per capita defense contracts }\end{array}$ & $\begin{array}{r}-0.166^{* * *} \\
(0.04)\end{array}$ & $\begin{array}{r}-0.036 \\
(0.023)\end{array}$ \\
\hline $\begin{array}{l}\text { MIL }\{0 \text { to } 5\} \\
\text { change in state-level per capita defense employment }\end{array}$ & $\begin{array}{r}-0.14^{* *} \\
(0.07)\end{array}$ & $\begin{array}{r}0.004 \\
(0.041)\end{array}$ \\
\hline $\begin{array}{l}\text { OIL }\{0 \text { to } 2\} \text { oil price growth interacted with state-level } \\
\text { employment mix }\end{array}$ & $\begin{array}{r}0.94^{* * *} \\
(0.12)\end{array}$ & $\begin{array}{r}0.40^{* * *} \\
(0.08)\end{array}$ \\
\hline $\begin{array}{l}\text { MXX }\{0 \text { to } 2\} \\
\text { state-level industry employment mix }\end{array}$ & $\begin{array}{r}-0.91^{* * *} \\
(0.20)\end{array}$ & $\begin{aligned}-0.69 * * * \\
(0.13)\end{aligned}$ \\
\hline $\begin{array}{l}\text { STOCK }\{0 \text { to } 2\} \\
\text { state-level stock market dispersion index }\end{array}$ & $\begin{array}{r}0.22^{*} \\
(0.12)\end{array}$ & $\begin{array}{r}0.20^{* * *} \\
(0.08)\end{array}$ \\
\hline \multicolumn{3}{|l|}{$\begin{array}{l}\text { Panel B: F-tests } \\
\text { (significance levels in parentheses) }\end{array}$} \\
\hline $\operatorname{CON}\{0$ to 5$\}$ & $\begin{array}{r}2.91 \\
(0.008)\end{array}$ & $\begin{array}{r}3.17 \\
(0.004)\end{array}$ \\
\hline $\operatorname{MIL}\{0$ to 5$\}$ & $\begin{array}{r}3.98 \\
(0.001)\end{array}$ & $\begin{array}{r}2.06 \\
(0.055)\end{array}$ \\
\hline OIL $\{0$ to 2$\}$ & $\begin{array}{r}48.88 \\
(0.000) \\
\end{array}$ & $\begin{array}{r}53.94 \\
(0.000) \\
\end{array}$ \\
\hline $\operatorname{MIX}\{0$ to 2$\}$ & $\begin{array}{r}55.29 \\
(0.000)\end{array}$ & $\begin{array}{r}144.56 \\
(0.000)\end{array}$ \\
\hline STOCK $\{0$ to 2$\}$ & $\begin{array}{r}3.22 \\
(0.022)\end{array}$ & $\begin{array}{r}3.57 \\
(0.014)\end{array}$ \\
\hline $\begin{array}{l}\text { Mean of dependent variable } \\
\text { (Standard error of dependent variable) }\end{array}$ & $\begin{array}{r}5.94 \\
(2.19)\end{array}$ & $\begin{array}{r}3.42 \\
(1.62)\end{array}$ \\
\hline Standard Error of the Estimate & .645 & .452 \\
\hline $\mathbf{R}^{2}$ & 0.92 & 0.93 \\
\hline Time period used in estimation & 1959 to 1992 & 1956 to 1992 \\
\hline Total number of observations & 1720 & 1864 \\
\hline
\end{tabular}


Notes to Table 2:

1. The regressions include state fixed effects and year fixed effects.

2. The independent variables have been scaled by their respective standard deviations over the 19581992 period.

3. In Panel A, the notation in $\{\ldots\}$ indicates the number of lags of the variable that are included in the regression. For example, $\operatorname{CON}\{0$ to 5$\}$ means that the regression contains the contemporaneous value and five lags of CON. The estimate reported is the sum of the estimated coefficients on the contemporaneous and lag values, and the standard error is the one associated with the sum.

Significance at the $1 \%$ level is indicated by "***", at $5 \%$ and $10 \%$ by "**" and "*" respectively.

- 4. In Panel B, the null hypothesis is that the contemporaneous and lagged values of the indicated variable can be excluded from the regression. 
Table 3

The Regional Cycle Component of Civilian Unemployment Rate Fluctuations: Cross-State Dispersion

\begin{tabular}{|c|c|c|}
\hline & Mean level over time & $\begin{array}{l}\text { Standard deviation of } \\
\text { movements over time }\end{array}$ \\
\hline $\begin{array}{l}\sigma_{\mathbf{t}} \\
\text { actual dispersion }\end{array}$ & 1.50 & 0.36 \\
\hline $\begin{array}{l}\sigma^{p} \\
\text { predicted dispersion }\end{array}$ & 1.33 & 0.29 \\
\hline $\begin{array}{l}\sigma^{p x} \\
\text { predicted dispersion - } \\
\text { "dynamic" version }\end{array}$ & 0.47 & 0.20 \\
\hline \multicolumn{3}{|c|}{ Components of dynamic $\sigma_{p}:$} \\
\hline$\sigma t^{P}[]$ & 0.18 & 0.09 \\
\hline$\sigma t^{p}[]$ & 0.10 & 0.08 \\
\hline$\sigma t^{p}[]$ & 0.26 & 0.28 \\
\hline$\sigma t^{p}[]$ & 0.22 & 0.11 \\
\hline$\sigma \mathfrak{t}^{p}[]$ & 0.13 & 0.06 \\
\hline
\end{tabular}


Table 4

The Regional Cycle Component Civilian of Unemeployment Rate Fluctuations:

Within-State Time Variation

\begin{tabular}{|c|c|c|c|}
\hline & $\begin{array}{l}\text { Mean } \\
\text { (across states) }\end{array}$ & $\begin{array}{l}\text { Standard } \\
\text { deviation } \\
\text { (across states) }\end{array}$ & $\begin{array}{l}\text { States with the five highest } \\
\text { values } \\
\text { (value is shown in parenthesis) }\end{array}$ \\
\hline $\begin{array}{l}\sigma_{\mathbf{s}} \\
\text { actual standard deviation }\end{array}$ & 1.92 & 0.44 & $\begin{array}{l}\text { West Virginia (3.22), Michigan (3.14), } \\
\text { Alabama (2.65), Rhode Island ( } 2.50) \text {, } \\
\text { Indiana (2.49) }\end{array}$ \\
\hline $\begin{array}{l}\sigma^{p s} \\
\text { predicted standard deviation }\end{array}$ & 1.81 & 0.35 & $\begin{array}{l}\text { Michigan (2.76), West Virginia (2.49), } \\
\text { Indiana (2.49), Alabama (2.38), Rhode } \\
\text { Island (2.24) }\end{array}$ \\
\hline $\begin{array}{l}\sigma^{\mathrm{ps}} \\
\text { predicted standard deviation - } \\
\text { "dynamic" version } \\
\end{array}$ & 2.13 & 0.30 & $\begin{array}{l}\text { Michigan (3.01), Indiana (2.72), } \\
\text { Delaware (2.55), Ohio (2.55), } \\
\text { S. Carolina (2.53) }\end{array}$ \\
\hline \multicolumn{4}{|l|}{ Components of $\sigma_{p s}:$} \\
\hline$\sigma t^{p}[]$ & 0.17 & 0.12 & $\begin{array}{l}\text { Delaware }(0.72) \text {, Connecticut }(0.47) \text {, } \\
\text { Utah }(0.39) \text {, Washington }(0.31) \text {, } \\
\text { Missouri }(0.30)\end{array}$ \\
\hline$\sigma \mathfrak{t}^{p}[]$ & 0.08 & 0.11 & $\begin{array}{l}\text { Alaska (0.58), D. C. }(0.50) \text {, } \\
\text { Hawaii }(0.34) \text {, Wyoming (0.18), } \\
\text { Virginia }(0.17)\end{array}$ \\
\hline$\sigma \mathfrak{t}^{p}[]$ & 1.67 & 0.35 & $\begin{array}{l}\text { Michigan (2.33), Indiana (2.15), } \\
\text { N. Carolina (2.11), S. Carolina (2.10), } \\
\text { Ohio (2.04) }\end{array}$ \\
\hline$\sigma \mathfrak{t}^{\mathrm{P}}[\mathrm{]}$ & 1.50 & 0.18 & $\begin{array}{l}\text { Michigan (2.04), Indiana (1.86), Ohio } \\
\text { (1.78), West Virginia (1.73), } \\
\text { N. Carolina (1.69) }\end{array}$ \\
\hline$\sigma \mathfrak{t}^{\mathrm{p}}[\mathrm{]}$ & 0.38 & 0.04 & $\begin{array}{l}\text { Wyoming }(0.56) \text {, New Mexico }(0.49) \text {, } \\
\text { Louisiana }(0.46) \text {, West Virginia } \\
(0.43) \text {, Florida }(0.43)\end{array}$ \\
\hline
\end{tabular}


Table 5: Spillovers

\begin{tabular}{|c|c|c|}
\hline $\begin{array}{l}\text { Panel A: Sums of Estimated Coefficients } \\
\text { (standard erros in parentheses) }\end{array}$ & (1) & (2) \\
\hline Dependent Variable & $\begin{array}{l}\text { civilian } \\
\text { unemployment }\end{array}$ & $\begin{array}{l}\text { insured } \\
\text { unemployment }\end{array}$ \\
\hline $\begin{array}{l}\text { CON }\{0 \text { to } 5\} \\
\text { change in state-level real, per capita defense contracts }\end{array}$ & $\begin{array}{r}-0.14^{-0 * \bullet} \\
(0.04)\end{array}$ & $-0.035 \quad(0.024)$ \\
\hline $\begin{array}{l}\text { CONR }\{0 \text { to } 5\} \\
\text { change in rest-of-division real, per capita def. contracts }\end{array}$ & $\begin{array}{r}-0.28^{* \cdots *} \\
(0.07)\end{array}$ & $\begin{array}{r}-0.098^{* 0 *} \\
(0.040)\end{array}$ \\
\hline $\begin{array}{l}\text { MIL }\{0 \text { to } 5\} \\
\text { change in state-level per capita defense employment }\end{array}$ & $\begin{array}{c}-0.11^{* *} \\
(0.06)\end{array}$ & $\begin{array}{l}0.002 \\
(0.035)\end{array}$ \\
\hline $\begin{array}{l}\text { MIL_REST }\{0 \text { to } 5\} \\
\text { change in rest-of-division per capita def. employment }\end{array}$ & $\begin{array}{l}-0.0002^{*} \\
(0.0001)\end{array}$ & $\begin{array}{r}0.0001 \\
(0.0001)\end{array}$ \\
\hline $\begin{array}{l}\text { OIL }\{0 \text { to } 2\} \text { oil price growth interacted with state-level } \\
\text { employment mix }\end{array}$ & $\begin{array}{r}0.97^{\circ * *} \\
(0.12)\end{array}$ & $\begin{array}{r}0.42^{* 0 *} \\
(0.08) \\
\end{array}$ \\
\hline $\begin{array}{l}\text { MIX }\{0 \text { to } 2\} \\
\text { state-level industry employment mix }\end{array}$ & $\begin{array}{r}-0.88^{* * *} \\
(0.20)\end{array}$ & $\begin{array}{r}-0.64 * * \\
(0.13) \\
\end{array}$ \\
\hline $\begin{array}{l}\text { STOCK }\{0 \text { to } 2\} \\
\text { state-level stock market dispersion index }\end{array}$ & $\begin{array}{r}0.16 \\
(0.12)\end{array}$ & $\begin{array}{r}0.21^{* * 0} \\
(0.08)\end{array}$ \\
\hline $\begin{array}{l}\text { Panel B: F-tests } \\
\text { (significance levels in parentheses) }\end{array}$ & & \\
\hline $\operatorname{CON}\{0$ to 5$\}$ & $\begin{array}{r}2.40 \\
(0.026) \\
\end{array}$ & $\begin{array}{r}3.19 \\
(0.004) \\
\end{array}$ \\
\hline CON_REST $\{0$ to 5$\}$ & $\begin{array}{r}2.78 \\
(0.011)\end{array}$ & $\begin{array}{r}3.18 \\
(0.004) \\
\end{array}$ \\
\hline $\operatorname{MIL}\{0$ to 5$\}$ & $\begin{array}{r}3.83 \\
(0.000)\end{array}$ & $\begin{array}{r}2.11 \\
(0.049)\end{array}$ \\
\hline MIL_REST $\{0$ to 5$\}$ & $\begin{array}{r}0.79 \\
(0.581) \\
\end{array}$ & $\begin{array}{r}0.59 \\
(0.735) \\
\end{array}$ \\
\hline $\operatorname{OIL}\{0$ to 2$\}$ & $\begin{array}{r}50.09 \\
(0.000)\end{array}$ & $\begin{array}{r}54.46 \\
(0.000) \\
\end{array}$ \\
\hline $\operatorname{MIX}\{0$ to 2$\}$ & $\begin{array}{r}54.97 \\
(0.000) \\
\end{array}$ & $\begin{array}{r}142.27 \\
(0.000) \\
\end{array}$ \\
\hline STOCK $\{0$ to 2$\}$ & $\begin{array}{r}2.46 \\
(0.061)\end{array}$ & $\begin{array}{r}3.85 \\
(0.009)\end{array}$ \\
\hline Standard error of the estimate & .644 & .451 \\
\hline$R^{2}$ & 0.92 & 0.93 \\
\hline Time period used in estimation & 1959 to 1992 & 1956 to 1992 \\
\hline Total number of observations & 1720 & 1864 \\
\hline
\end{tabular}


Notes to Table 5:

1. The regressions include state fixed effects, year fixed effects and two lags of the dependent variable.

2. The independent variables have been scaled by their respective standard deviations over the 1958 to 1992 period, except as follows: CONR is scaled by the standard deviation of CON, and MILR is scaled by the standard deviation of MII.

See also notes 3 and 4 to Table 2. 
Table 6: Arymesies

\begin{tabular}{|c|c|c|c|c|}
\hline \multirow{2}{*}{ 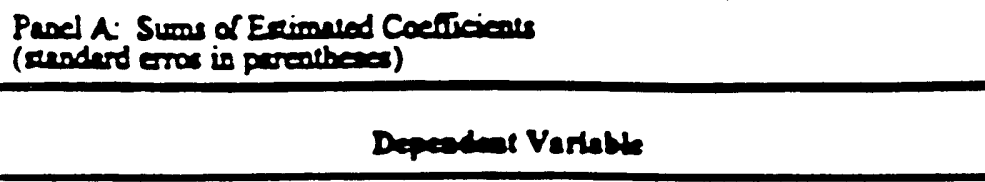 } & \multicolumn{2}{|c|}{ (1) } & \multicolumn{2}{|c|}{ (2) } \\
\hline & \multicolumn{2}{|c|}{$\begin{array}{l}\text { dillin } \\
\text { inemployerest }\end{array}$} & \multicolumn{2}{|c|}{$\begin{array}{l}\text { Insured } \\
\text { necepploymeat }\end{array}$} \\
\hline 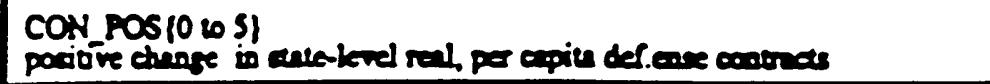 & & $\begin{array}{l}-0.12^{\circ} \\
(0.06)\end{array}$ & & $\begin{array}{l}0.05 \\
(0.04)\end{array}$ \\
\hline 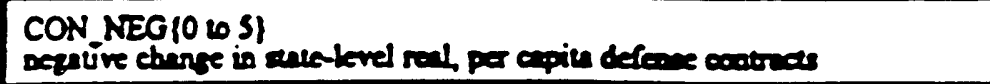 & & $\begin{array}{l}0.23^{-} \\
(0.06)\end{array}$ & & $\begin{array}{l}-0.05 \\
(0.03)\end{array}$ \\
\hline 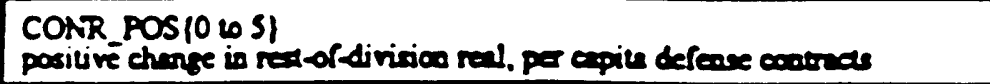 & & $\begin{array}{l}0.25^{-} \\
(0.12)\end{array}$ & & $\begin{array}{r}0.24- \\
(0.07)\end{array}$ \\
\hline 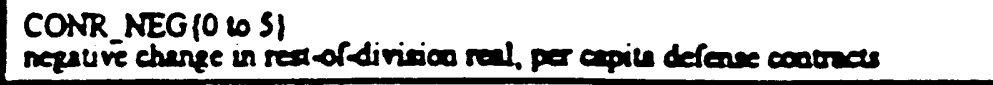 & & $\begin{array}{l}0.46^{-} \\
(0.12)\end{array}$ & & $0.22 \infty$ \\
\hline \multicolumn{5}{|l|}{ 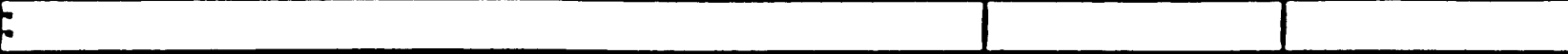 } \\
\hline 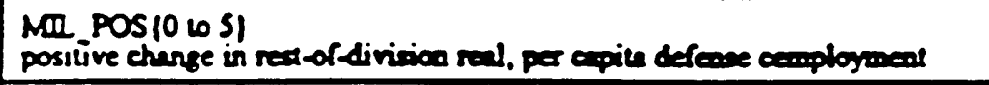 & & $\begin{array}{c}0.02 \\
(0.10)\end{array}$ & & $\begin{array}{l}0.07 \\
(0.06)\end{array}$ \\
\hline 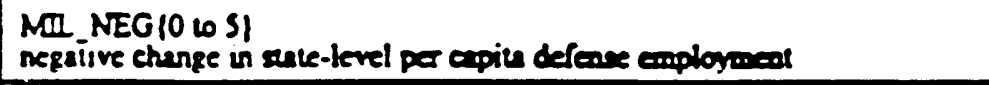 & & $(0.09)^{-}$ & & $\begin{array}{l}20.02 \\
(0.05)\end{array}$ \\
\hline 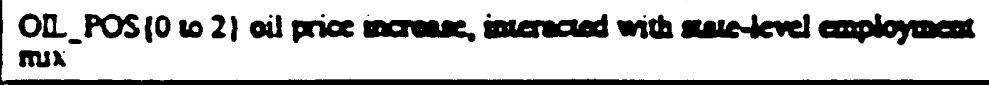 & & $\begin{array}{l}1.10^{-} \\
(020)\end{array}$ & & $\begin{array}{l}0.63^{-} \\
(0.13)\end{array}$ \\
\hline 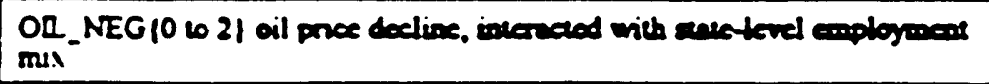 & & $\begin{array}{l}0.7 \pi^{\infty} \\
(021)\end{array}$ & & $\begin{array}{l}0.20 \\
(0.15)\end{array}$ \\
\hline \multicolumn{5}{|l|}{ 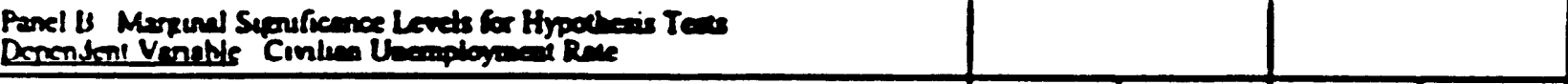 } \\
\hline $\begin{array}{l}\text { Null lliphesis } \\
\text { Simmen Coeficient Suros }\end{array}$ & $\begin{array}{l}\text { CON } \\
.15\end{array}$ & $\begin{array}{c}\operatorname{con} R \\
25\end{array}$ & $\begin{array}{l}\text { Noll } \\
.09\end{array}$ & $3^{\text {OL }}$ \\
\hline inunien Insurbutal Leps & .49 & .00 & .05 & 79 \\
\hline Exclusion of Possure Values & .67 & .00 & .03 & .00 \\
\hline Evelussion of Nepative Valus & .01 & .10 & .00 & .00 \\
\hline \multicolumn{5}{|l|}{ 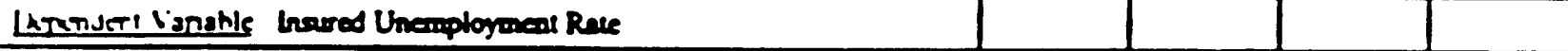 } \\
\hline Simmeth CoeTierent Surws & .93 & .13 & .30 & .06 \\
\hline Simmeen Insenbulad Lees & .33 & .00 & .33 & 25 \\
\hline Exclusion of Possurve Values & .03 & .00 & .29 & .00 \\
\hline Exclusion of Nepative Values & .07 & .00 & .02 & .00 \\
\hline SLandars Error of the Exumale & \multicolumn{2}{|c|}{.639} & \multicolumn{2}{|c|}{.46} \\
\hline$R^{:}$ & \multicolumn{2}{|c|}{0.92} & \multicolumn{2}{|c|}{0.93} \\
\hline Time period used I coimaice & \multicolumn{2}{|c|}{1959 10 1992} & \multicolumn{2}{|c|}{1956 w 1992} \\
\hline Tocel number of obcervacuens & \multicolumn{2}{|c|}{1720} & \multicolumn{2}{|c|}{1864} \\
\hline
\end{tabular}


Notes to Table 6:

1. The regressions include state fixed effects, year fixed effects, two lags of the dependent variable, $\operatorname{MIX}\{0$ to 2$\}$ and STDISP $\{0$ to 2$\}$.

2. The independent variables are scaled in the same manner as in Table 5. For example, CON_POS, CON_NEG, CONR_POS and CONR_NEG are all scaled by the standard deviation of CON over the 1958 to 1992 period. 


\section{TABLE 7}

Military Spending and jobs: some illustrative calculations

Panel A: Estimated Cost of unit increase in employment [based on VAR estimates]

\begin{tabular}{|c|c|c|c|}
\hline $\begin{array}{c}\text { (1) Discount } \\
\text { rate }\end{array}$ & $\begin{array}{c}\text { (2) Cost per job } \\
\text { (based on CPS } \\
\text { employment measure) }\end{array}$ & $\begin{array}{c}\text { (3) Cost per job } \\
\text { (based on BLS } \\
\text { employment measure) }\end{array}$ & $\begin{array}{c}\text { (4) Cost per job } \\
\text { (column (3) estimates with } \\
\text { spillover adjustment) }\end{array}$ \\
\hline $3 \%$ & $\$ 197,484$ & $\$ 90,698$ & $\$ 56,115$ \\
\hline $5 \%$ & $\$ 175,229$ & $\$ 70,632$ & $\$ 43,478$ \\
\hline $10 \%$ & $\$ 158,730$ & $\$ 56,497$ & $\$ 34,364$ \\
\hline
\end{tabular}

Panel B: Estimated Cost of unit reduction in unemployment

[based on VAR estimates]

\begin{tabular}{|c|c|c|c|}
\hline $\begin{array}{c}\text { (1) Discount } \\
\text { rate }\end{array}$ & $\begin{array}{c}\text { (2) Cost per person } \\
\text { (based on insured } \\
\text { unemployment rate) }\end{array}$ & $\begin{array}{c}\text { (3) Cost per person } \\
\text { (based on civilian } \\
\text { unemployment rate) }\end{array}$ & $\begin{array}{c}\text { (4) Cost per person } \\
\text { (column (3) estimates with } \\
\text { spillover adjustment) }\end{array}$ \\
\hline $3 \%$ & $\$ 4,485,714$ & $\$ 2,080,000$ & $\$ 1,155,556$ \\
\hline $5 \%$ & $\$ 2,742,857$ & $\$ 1,357,143$ & $\$ 760,000$ \\
\hline $10 \%$ & $\$ 1,166,667$ & $\$ 825,000$ & $\$ 150,000$ \\
\hline
\end{tabular}

Panel C: Estimated Cost of unit reduction in unemployment [based on OLS estimates in Tables $2 \& 5$ ]

\begin{tabular}{|c|c|c|c|}
\hline $\begin{array}{c}\text { (1) Discount } \\
\text { rate }\end{array}$ & $\begin{array}{c}\text { (2) Cost per person } \\
\text { (based on insured } \\
\text { unemployment rate) }\end{array}$ & $\begin{array}{c}\text { (3) Cost per person } \\
\text { (based on civilian } \\
\text { unemployment rate) }\end{array}$ & $\begin{array}{c}\text { (4) Cost per person } \\
\text { (column (3) estimates with } \\
\text { spillover adjustment) }\end{array}$ \\
\hline $3 \%$ & $\$ 3,633,333$ & $\$ 1,923,529$ & $\$ 1,054,839$ \\
\hline $5 \%$ & $\$ 2,155,556$ & $\$ 1,212,500$ & $\$ 692,857$ \\
\hline $10 \%$ & $\$ 1,187,500$ & $\$ 678,571$ & $\$ 431,818$ \\
\hline
\end{tabular}



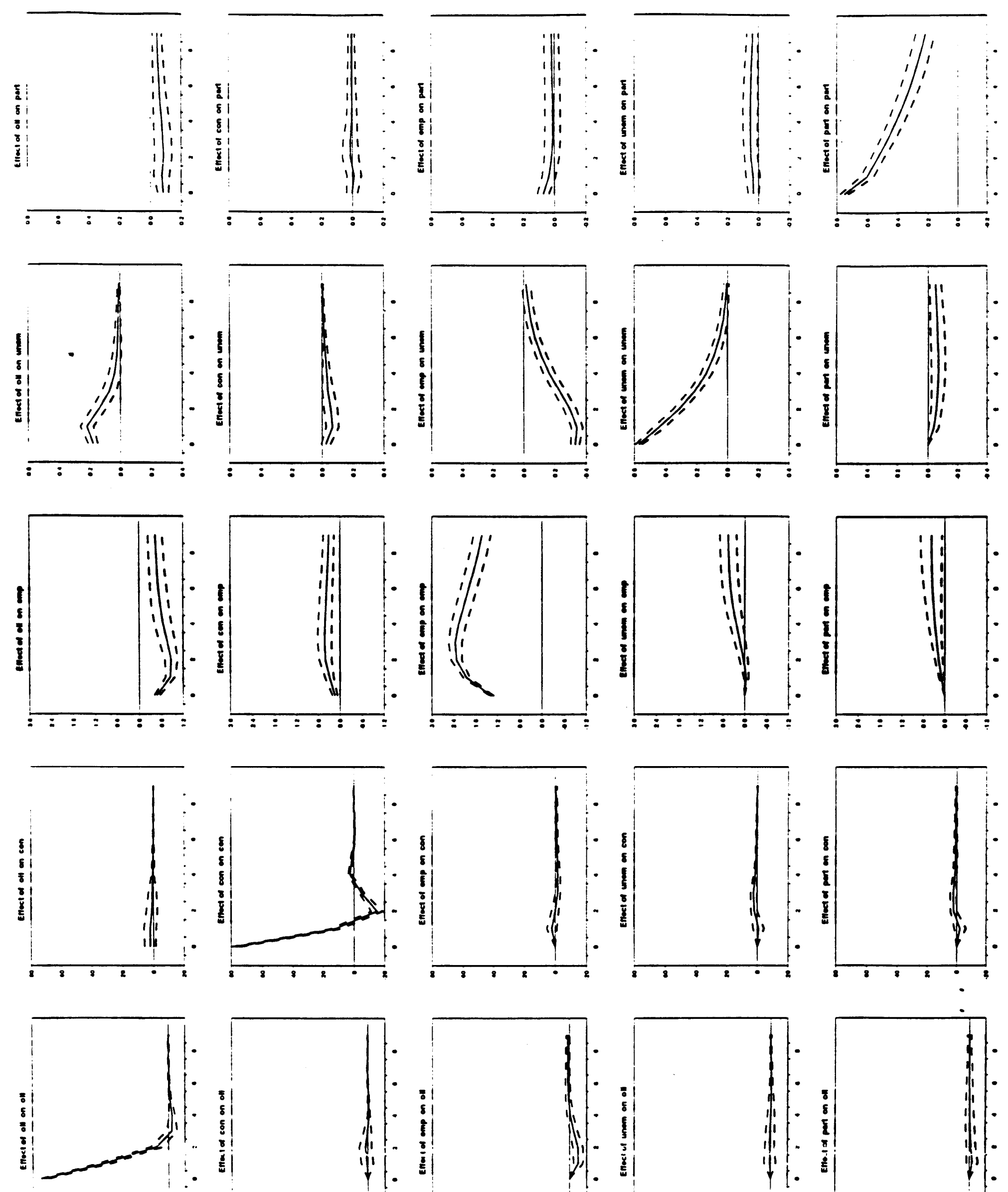
F1gure A.2
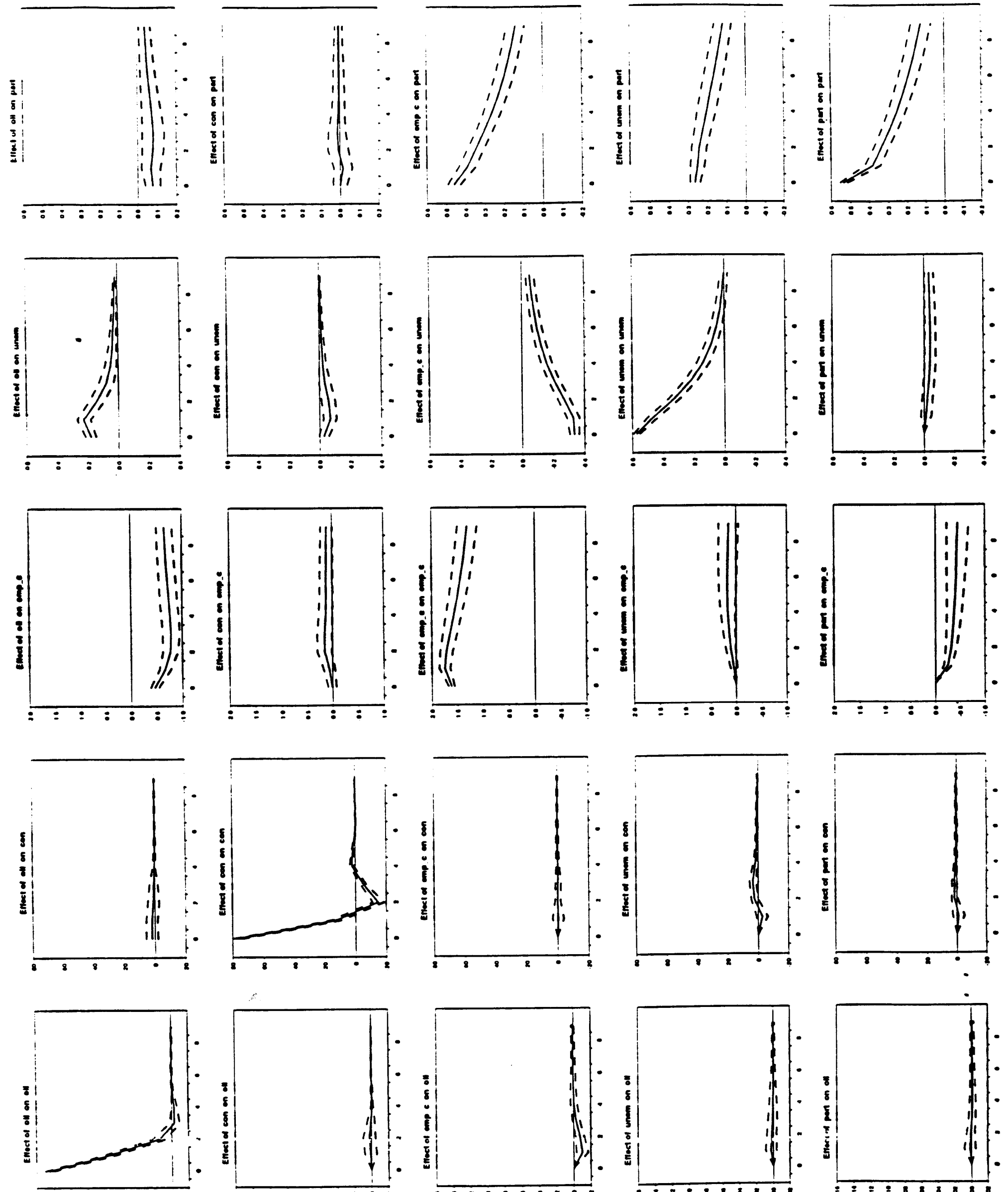